\title{
Effects of lipopolysaccharide exposure in primary bovine ruminal epithelial cells
}

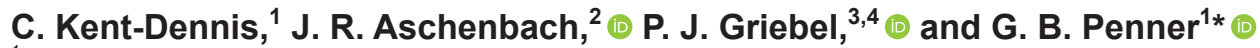 \\ ${ }^{1}$ Department of Animal and Poultry Science, University of Saskatchewan, Saskatoon, SK, Canada, S7N 5A8 \\ ${ }^{2}$ Institute of Veterinary Physiology, Freie Universität Berlin, D-14163, Berlin, Germany \\ ${ }^{3}$ Vaccine and Infectious Disease Organization/Intervac, University of Saskatchewan, Saskatoon, SK, Canada, S7N 5E3 \\ ${ }^{4}$ School of Public Health, University of Saskatchewan, Saskatoon, SK, Canada, S7N $2 Z 4$
}

\begin{abstract}
The objective of this study was to investigate whether cultured ruminal epithelial cells (REC) responded to lipopolysaccharide (LPS) stimulation and determine whether LPS induced a proinflammatory response. Primary bovine REC were isolated and grown in culture for 2 studies. In study 1, REC were isolated from Holstein bull calves $(\mathrm{n}=8)$ and grown in culture for 10 to $12 \mathrm{~d}$. Cells were then exposed to 0,10,000, 50,000, or 200,000 endotoxin (E) $\mathrm{U} / \mathrm{mL}$ of LPS (Escherichia coli O55:B5) for either 6 or $24 \mathrm{~h}$. The effect of LPS exposure on cell viability was analyzed by flow cytometry using a propidium iodide stain. In study 2 , cells were isolated from Holstein bull calves $(\mathrm{n}=5)$ and yearling beef heifers ( $\mathrm{n}$ $=4$ ). Cells were exposed to either 1,000 or $50,000 \mathrm{EU} /$ $\mathrm{mL}$ of LPS using the following conditions: (1) medium alone time-matched controls, (2) 12-h LPS exposure, (3) $24 \mathrm{~h}$ of LPS exposure, (4) $36 \mathrm{~h}$ of LPS exposure, (5) $12 \mathrm{~h}$ of LPS exposure followed by LPS removal for $24 \mathrm{~h}$ before restimulating with LPS for an additional $12 \mathrm{~h}$ (RPT), and (6) $12 \mathrm{~h}$ of LPS exposure followed by LPS removal for 36 (RVY). For both experiments, total RNA was extracted from REC and real-time quantitative PCR was performed to determine relative expression of genes for toll-like receptors (TLR2 and $T L R 4)$, proinflammatory cytokines (TNF and $I L 1 B)$, chemokines ( $C X C L 2$ and $C X C L 8)$, a lipid mediator (PTGS2), and growth factor-like cytokines (CSF2 and $I L 7)$. In study 1 , LPS exposure did not negatively affect cell viability. Treatment of cells with LPS resulted in increased transcript abundance for all genes analyzed. The TLR2, IL7, and TLR4 had a greater magnitude of change at $6 \mathrm{~h}$ compared with $24 \mathrm{~h}$. Quadratic expression patterns were detected for TNF, IL1B, CXCL2, $C X C L 8$, and CSF2. These results suggested that REC
\end{abstract}

\footnotetext{
Received April 4, 2020.

Accepted May 21, 2020.

*Corresponding author: greg.penner@usask.ca
}

increase expression of proinflammatory genes following exposure to LPS. In study 2, all genes analyzed were upregulated in a quadratic manner following exposure to LPS for different time intervals. The TLR 4, TNF, CXCL2, CXCL8, CSF2, and IL7 gene expression was significantly greater after a single $12 \mathrm{~h}$ of LPS exposure than after RPT exposure, suggesting repeated exposure of REC to LPS may induce a tolerogenic effect. When LPS was removed from the medium (RVY), transcript abundance for all genes analyzed decreased and expression of TLR2, TLR4, and IL7 returned to baseline levels, suggesting REC recovered following exposure to LPS. Overall, the data suggest cultured REC respond to LPS stimulation by increasing transcription of proinflammatory genes and this transcriptional response was influenced by the dose, duration, and frequency of LPS exposure.

Key words: cell culture, gene expression, inflammation, lipopolysaccharide, rumen epithelium

\section{INTRODUCTION}

Diets containing highly fermentable carbohydrates are often fed to high-producing dairy cows (Penner et al., 2009) and finishing beef cattle (Loerch, 1990; Wierenga et al., 2010) to meet their energy requirements. However, diets that result in rapid rates of carbohydrate fermentation also increase the risk for ruminal acidosis. As such, ruminal acidosis occurs when rapid rates of short-chain fatty acid production lead to decreased ruminal $\mathrm{pH}$ and increased ruminal osmolality (Nocek, 1997; Penner et al., 2010). In addition, an increase in the concentration of microbe-associated molecular patterns (MAMP) molecules, such as LPS, in ruminal fluid has been reported in cattle fed highly fermentable diets (Nagaraja et al., 1978; Khafipour et al., 2009), presumably as a result of increased bacterial cell lysis (Plaizier et al., 2008).

Low ruminal $\mathrm{pH}$ with increased short-chain fatty acid concentration of ruminal fluid, as well as increased 
osmolality, have been reported to disrupt epithelial barrier function, increasing the permeability of the ruminal epithelium (Aschenbach and Gabel, 2000; Penner et al., 2010; Meissner et al., 2017), which may lead to translocation of ruminal LPS, bacteria, or other MAMP molecules into peripheral tissue and the induction of a systemic inflammatory response (Khafipour et al., 2009; Aschenbach et al., 2019). Through binding with pattern recognition receptors (PRR), such as toll-like receptors, this translocation of MAMP may result in an interaction between luminal-derived MAMP and ruminal epithelial cells (REC), potentially triggering a local innate immune response ( $\mathrm{Li}$ et al., 2012; Pan et al., 2017).

Bovine ruminal tissue has been reported to express PRR (Malmuthuge et al., 2012), but PRR expression can occur in many different cell types present within a tissue (Schilling et al., 2003; Najar et al., 2017). Previous studies (Dionissopoulos et al., 2012; Liu et al., 2013; Arroyo et al., 2017) used ruminal papillae to investigate local inflammatory responses. Pan et al. (2017) showed that expression of genes encoding for proinflammatory cytokines, $T N F, I L 1 B$, and $I L 6$, was upregulated in ruminal epithelial tissue in dairy cows fed high-grain diets. Other studies, despite detecting increased ruminal fluid LPS following high-grain diets, have reported no effect (Dionissopoulos et al., 2012), or even an anti-inflammatory effect (Minuti et al., 2015; Kent-Dennis et al., 2019), suggesting that the inflammatory response in the ruminal epithelium is tightly regulated, as is the case in other tissues (Sugimoto et al., 2016). A direct role of REC in these inflammatory responses, however, could not be ascertained due to the heterogeneous nature of ruminal tissue. Zhang et al. (2016) provided evidence that cultured REC increased expression of proinflammatory cytokine genes, including $I L 1 B, T N F$, and $C X C L 8$, in response to LPS stimulation, suggesting that REC respond canonically. In addition to the classical, proinflammatory cytokines, molecules that regulate the phases of inflammation, such as lipid mediators and growth factor-like cytokines, may also be differentially expressed in the ruminal epithelium (Kent-Dennis et al., 2019). However, expression of such molecules has not been previously evaluated in REC. Further investigation is necessary to elucidate the potential for and regulation of a local inflammatory response initiated by REC. The purpose of the present study was to investigate changes in expression of proinflammatory genes when isolated REC were exposed to different concentrations, durations, and frequencies of LPS exposure to better elucidate the potential role of REC in the local inflammatory response.

\section{MATERIALS AND METHODS}

This study was preapproved by the University of Saskatchewan Animal Research Ethics Board (protocol 20110127) and was conducted in accordance with guidelines set forth by the Canadian Council of Animal Care (Ottawa, ON, Canada). Tissue for this study was obtained from Holstein bull calves (protocol 20160076) and yearling beef heifers (protocol 20100021) that were killed for use in unrelated experiments, the conditions of which were not expected to alter the rumen epithelium. Bull calves were killed by intravenous injection of $20 \mathrm{~mL}$ of Euthanyl (Bimeda-MTC, Cambridge, ON, Canada) $/ 45 \mathrm{~kg}$ of BW and beef heifers were killed by captive bolt stunning followed by exsanguination.

\section{Experiment 1: Dose-Dependent Cytotoxicity and Inflammatory Response to LPS}

Animals and Tissue Collection. Tissues for this experiment were obtained from 4-mo-old Holstein bull calves $(\mathrm{n}=8)$ group housed in an outdoor, dry-lot pen. Calves had ad libitum access to water and mixed brome-alfalfa hay and were fed $1.7 \mathrm{~kg}$ of pelleted ration (16\% CP; Co-op Elite Breeder Power Creep Beef Ration DEC Pellet, Saskatoon, SK Canada)/ $100 \mathrm{~kg}$ of BW per d. Within 15 min after euthanasia, ruminal tissue $\left(\sim 20 \mathrm{~cm}^{2}\right)$ was excised from the ventral sac. The tissue was washed thoroughly with ice-cold $\mathrm{Ca}^{2+}$ - and $\mathrm{Mg}^{2+}$ free Dulbecco's phosphate buffered saline (DPBS; Sigma-Aldrich, St. Louis, MO) containing antibiotics (final concentration: $400 \mathrm{U} / \mathrm{mL}$ penicillin, $400 \mu \mathrm{g} / \mathrm{mL}$ streptomycin, and $1 \mu \mathrm{g} / \mathrm{mL}$ amphotericin B; Thermo Fisher Scientific, Waltham, MA) and an antimycotic agent (Nystatin, $240 \mathrm{U} / \mathrm{mL}$; Sigma), and then transported in the same buffer on ice to the laboratory.

Ruminal Epithelial Cell Isolation and Cultivation. The procedure for isolation and cultivation of REC was adapted from Gálfi et al. (1980). All DPBS used with the ruminal tissue contained an antibioticantimycotic at a final concentration of $100 \mathrm{U} / \mathrm{mL}$ penicillin, $100 \mu \mathrm{g} / \mathrm{mL}$ streptomycin, and $0.25 \mu \mathrm{g} / \mathrm{mL}$ amphotericin B (Thermo Fisher).

Ruminal papillae were cut off at their base and washed thoroughly in $\mathrm{Ca}^{2+}$ - and $\mathrm{Mg}^{2+}$-free DPBS solution. Papillae were subjected to serial trypsinization using a trypsin-EDTA solution (0.25\% trypsin and $0.02 \%$ EDTA; Sigma), with an initial papillae to trypsinization solution ratio of $30 \mathrm{~g} / 50 \mathrm{~mL}$. Papillae were agitated in the trypsin solution at $37^{\circ} \mathrm{C}$ and the supernatant was collected and replaced with fresh solution every $30 \mathrm{~min}$. The first 2 fractions of supernatant were discarded. Frac- 
tions 3 through 6 were strained through sterile gauze to remove cellular detritus. Each fraction was centrifuged at $200 \times g$ at room temperature for $5 \mathrm{~min}$. Cell pellets were resuspended in with sterile DPBS with $\mathrm{Ca}^{2+}$ and $\mathrm{Mg}^{2+}$ and washed 3 times using the same centrifugation conditions as described above. Cell pellets from fractions 3 through 6 were then pooled and resuspended in 20 to $30 \mathrm{~mL}$ of M199 cell culture medium (Sigma) containing fetal bovine serum $(15 \% \mathrm{vol} / \mathrm{vol}$; Thermo Fisher), L-glutamine (1.36 m $M$; Sigma), HEPES (20 $\mathrm{m} M$; Sigma), antibiotic-antimycotic (final concentrations of $100 \mathrm{U} / \mathrm{mL}$ penicillin, $100 \mu \mathrm{g} / \mathrm{mL}$ streptomycin, $0.25 \mu \mathrm{g} / \mathrm{mL}$ amphotericin B (Thermo Fisher), plus 240 $\mathrm{U} / \mathrm{mL}$ nystatin (Sigma), $50 \mathrm{mg} / \mathrm{L}$ gentamycin (Sigma), and $100 \mathrm{mg} / \mathrm{L}$ kanamycin (Thermo Fisher). Cell suspensions were seeded into $60-\mathrm{mm}$ cell culture plates coated with bovine collagen I (Thermo Fisher). Seeding was conducted to ensure a high density of small round cells (Stumpff et al., 2011). Plates were placed in an incubator at $37^{\circ} \mathrm{C}$ with $5 \% \mathrm{CO}_{2}$ humidified atmosphere. One day after seeding, plates were washed with DPBS containing $\mathrm{Ca}^{2+}$ and $\mathrm{Mg}^{2+}$ to remove nonattached cellular detritus and fresh culture medium was added. On d 2 , cells were washed again with DPBS and the medium was replaced with minimum essential media (MEM) cell culture medium with stable L-glutamine (Sigma) containing fetal bovine serum $(10 \% \mathrm{vol} / \mathrm{vol}$; Thermo Fisher), HEPES (20 m M; Sigma), and antibiotic-antimycotic combination (final concentrations of $100 \mathrm{U} / \mathrm{mL}$ penicillin, $100 \mu \mathrm{g} / \mathrm{mL}$ streptomycin, and $0.25 \mu \mathrm{g} / \mathrm{mL}$ amphotericin B; Thermo Fisher). Culture medium was then replaced every 2 to $3 \mathrm{~d}$. After 10 to $12 \mathrm{~d}$ in culture, a subset of cells was stained with a mouse anti-CD90 antibody (final concentration: $0.02 \mathrm{mg} / \mathrm{mL}$; Novus Biologicals, Centennial, CO) followed by a goat-anti mouse Alexa Fluor 488 secondary (Abcam, Cambridge, UK). Percentage of fibroblast contamination was then determined by flow cytometry using an Accuri C6 (BD Biosciences, Franklin Lakes, NJ) based on a minimum of 5,000 events, and data analysis was performed with FlowJo version 10.0.7 (BD Biosciences). Cultures with $<10 \%$ of CD90-positive cells were considered acceptable (Kisselbach et al., 2009) and were reseeded into 24-well culture plates (Thermo Fisher). To reseed the cells, medium was aspirated and the plates were washed twice with DPBS. Two milliliters of warmed trypsinEDTA (0.25\% trypsin and 0.02\% EDTA; Sigma) was added to each plate and the plates were incubated for $12 \mathrm{~min}$. Immediately following incubation, the detached cells were transferred into a 50-mL tube (Thermo) with $4 \mathrm{~mL}$ of MEM and centrifuged at $200 \times g$ for $5 \mathrm{~min}$ at room temperature. Subsequently, the supernatant was decanted, the cell pellet was resuspended in $5 \mathrm{~mL}$ of MEM, and the cells were counted using a hemocytom- eter. Cells were reseeded at a rate of $8 \times 10^{4}$ cells $/ \mathrm{mL}$ ( $1 \mathrm{~mL}$ of medium per well). Cells were grown for $3 \mathrm{~d}$, until approximately $90 \%$ confluent, at which point they were used for the LPS exposure experiment. The REC isolated from each animal were cultured as separate cell lines.

LPS Dose Response and Stimulation Time. The LPS used in this study was from Escherichia coli O55:B5 (L6529, Lot 126M4087V; Sigma) and was reconstituted in sterile DPBS to a stock concentration of $2.1 \times 10^{6}$ endotoxin units $(\mathrm{EU}) / \mathrm{mL}$. The LPS used for the entire experiment was derived from the same lot to maintain consistent LPS activity levels. The stock was stored in $200-\mu \mathrm{L}$ aliquots at $-20^{\circ} \mathrm{C}$, as per the manufacturer's instructions. The isolated REC were exposed to $0,10,000,50,000$, or $200,000 \mathrm{EU} / \mathrm{mL}$ of LPS (3 replicate wells per treatment), for either 6 or $24 \mathrm{~h}$, with 1 plate per time point for each biological replicate of isolated REC. Following exposure to LPS, 1 well for each LPS dose and time point was trypsinized and cells were immediately analyzed for viability using propidium iodide (BioVision Inc., Milpitas, CA) staining to quantify the percent of dead cells with a flow cytometer (BDC6, BD Biosciences). The remaining 2 wells for each dose and time point were lysed in $1 \mathrm{~mL}$ of Trizol (Thermo Fisher), pooled, and frozen at $-80^{\circ} \mathrm{C}$ until used for RNA extraction.

Extraction of RNA and Analysis of Gene Expression. Total RNA was isolated by phenolchloroform extraction with 2 isopropanol precipitations (Kent-Dennis et al., 2019) and the addition of linear acrylamide (Thermo Fisher) as a co-precipitant. The RNA integrity was analyzed with a $1.2 \%$ (wt/vol) denaturing agarose gel and distinct $28 \mathrm{~S}$ and $18 \mathrm{~S}$ ribosomal RNA bands were confirmed in all samples before use in subsequent steps. The high capacity cDNA reverse transcription kit (Thermo Fisher) was used to reverse transcribe $1 \mu \mathrm{g}$ of RNA. The resulting cDNA was diluted to a final concentration of $10 \mathrm{ng} / \mu \mathrm{L}$ with nuclease-free water. Quantitative real-time PCR (qRTPCR) was performed using $20 \mathrm{ng}$ of cDNA and run in duplicate using SsoFast EvaGreen Supermix (Bio-Rad, Hercules, CA) using a CFX96 Touch Real-Time PCR detection system (Bio-Rad). Primers (IDT, Coralville, IA) were designed to span exon-exon junctions, where possible, and were assessed for dimer formation by generating melt curves following amplification to verify the presence of a single product. Primers designed for housekeeping genes and genes of interest are listed in Table 1. Before qRT-PCR analysis, primer efficiencies were calculated from a serial dilution of pooled cDNA samples. Housekeeping genes were assessed for effects of treatment and time, and no significant effects were detected $(P \geq 0.22$; data not shown). Therefore, all 3 
Table 1. Primer information

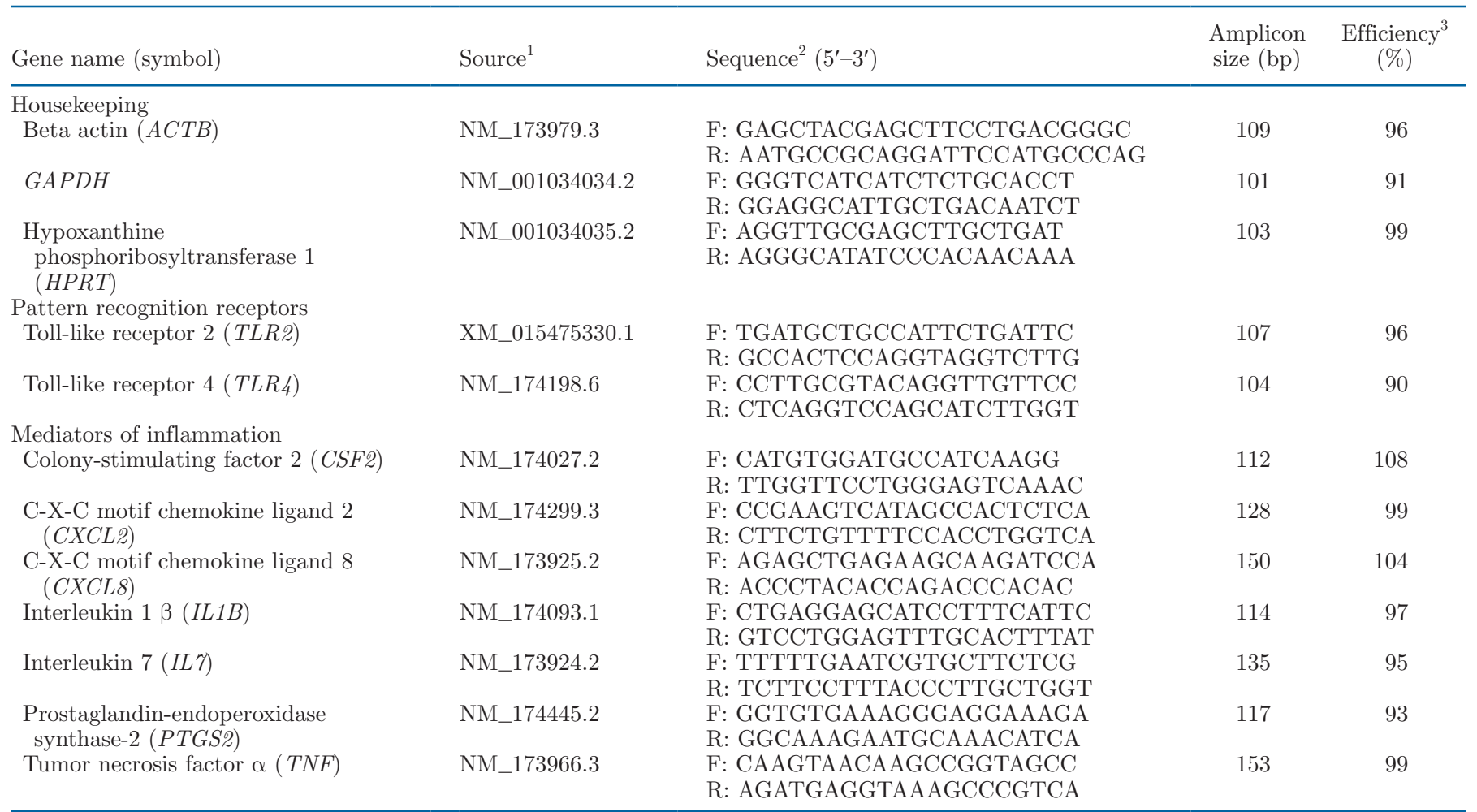

${ }^{1}$ National Center for Biotechnology Information (NCBI; Bethesda, MD).

${ }^{2} \mathrm{~F}=$ forward; $\mathrm{R}=$ reverse.

${ }^{3}$ Efficiency $=-1+10^{(-1 / \text { slope })} \times 100$.

genes were determined to be stable. The cycle threshold (Ct) values of the genes of interest were normalized to the geometric mean of the 3 housekeeping genes. Changes in gene expression were calculated as fold change using the formula $2^{-\Delta \Delta \mathrm{Ct}}$ (Pasternak et al., 2020). Expression of treatments was held relative to the mean of the time-matched medium control within animal.

\section{Study 2: Repeated LPS exposure}

Animals and Tissue Collection. Ruminal papillae collected from the ventral sac of 4-mo-old Holstein bull calves $(\mathrm{n}=5)$ and yearling beef heifers $(\mathrm{n}=4)$ were used for this experiment. The procedures for ruminal tissue collection and for isolation and cultivation of REC were performed as described for study 1 .

LPS Dose, Stimulation Time, and Frequency. Isolated REC were exposed to either low or high $(1,000$ or $50,000 \mathrm{EU} / \mathrm{mL}$, respectively) concentrations of LPS and subjected to one of the following exposure conditions (Figure 1): (1) $0 \mathrm{~h}$ of LPS exposure (CON), (2) $36 \mathrm{~h}$ of exposure $(\mathbf{3 6 H}),(3) 24 \mathrm{~h}$ of exposure $(\mathbf{2 4 H})$,
(4) $12 \mathrm{~h}$ of exposure $(\mathbf{1 2 H})$, (5) $12 \mathrm{~h}$ of exposure followed by removal of LPS for $24 \mathrm{~h}$ and then $12 \mathrm{~h}$ of exposure was repeated (RPT), and (6) $12 \mathrm{~h}$ of exposure followed by removal of LPS and a recovery period of $36 \mathrm{~h}$ (RVY). The starting point for administration of LPS was staggered such that cell collections from all cultures occurred at the same time. Two wells (for each treatment and time point) were lysed in $1 \mathrm{~mL}$ of Trizol (Thermo Fisher), pooled, and frozen at $-80^{\circ} \mathrm{C}$ until used for RNA extraction.

Extraction of RNA and Analysis of Gene Expression. Extraction of RNA and qRT-PCR procedures were performed as described for experiment 1. The Ct values of the genes of interest were normalized to the geometric mean of 3 stable housekeeping genes. Changes in gene expression were calculated as described previously.

\section{Statistical Analysis}

All statistical analyses were performed as a mixed model using the MIXED procedure of SAS 9.4 (SAS Institute Inc., Cary, NC). Analysis of qRT-PCR data 


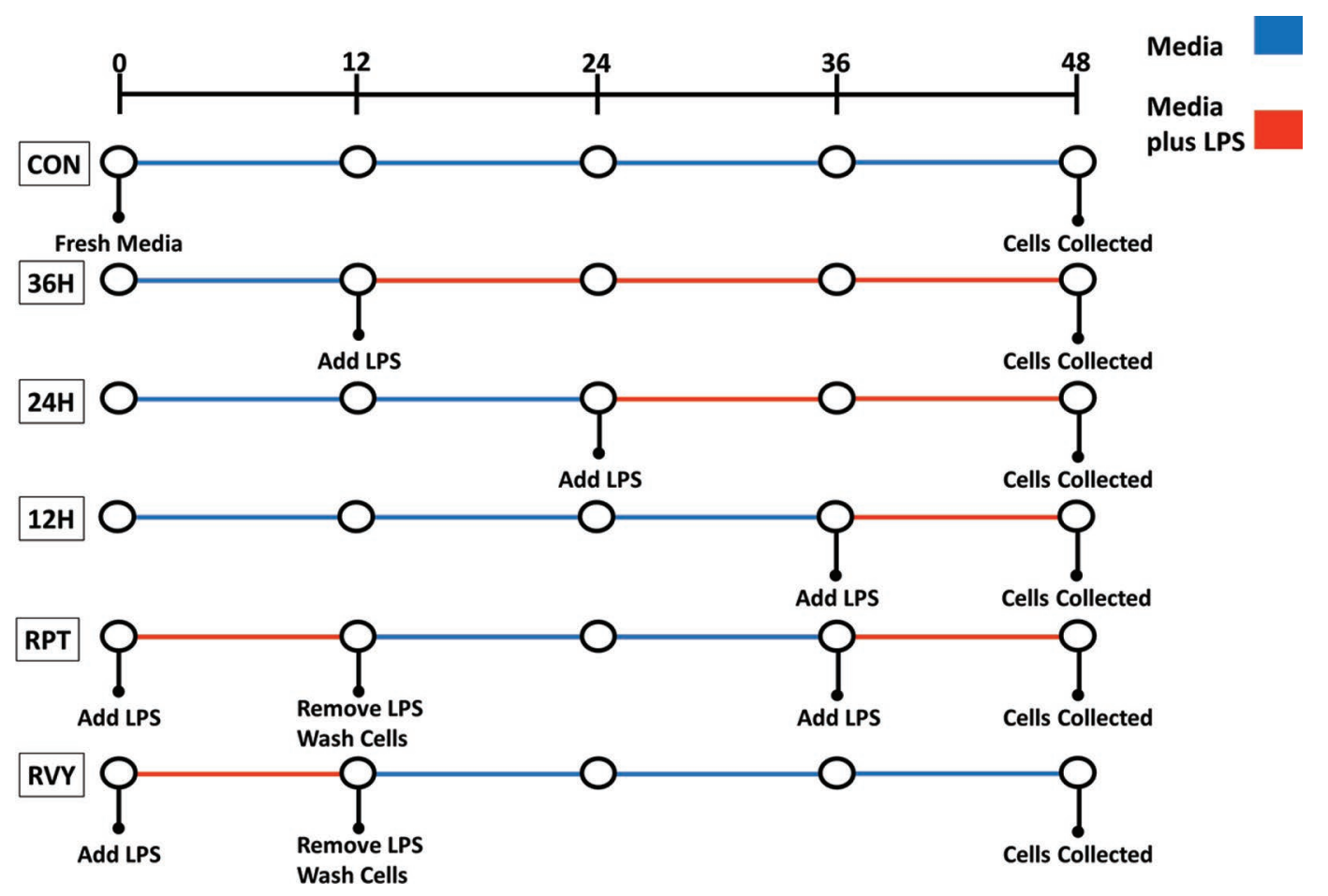

Figure 1. Schematic diagram of experimental conditions used in experiment 2. Treatments included the following: 0 h of LPS exposure $(\mathrm{CON}), 12 \mathrm{~h}$ of exposure followed by removal of LPS for $24 \mathrm{~h}$ and then $12 \mathrm{~h}$ of exposure was repeated (RPT), $12 \mathrm{~h}$ of exposure followed by removal of LPS and a recovery period of $36 \mathrm{~h}$ (RVY), $36 \mathrm{~h}$ of exposure $(36 \mathrm{H}), 24 \mathrm{~h}$ of exposure $(24 \mathrm{H})$, and $12 \mathrm{~h}$ of exposure (12H). Administration of treatments and sample collections for cells from individual animals occurred in a sequence that facilitated collection of cells from all cultures at the same 48 -h time point.

was performed on $\Delta \mathrm{Ct}$ and results are presented as fold change. Significance was declared at $P<0.05$.

Experiment 1. Data were analyzed with polynomial contrasts to evaluate whether viability or gene expression responded to LPS concentration in a linear or quadratic pattern, and coefficients were determined to account for unequal spacing. Treatment, duration (hours of exposure), and the treatment $\times$ duration interaction were considered fixed effects. Triplicate well (of culture plate) within animal was considered as the random effect.

Experiment 2. Treatment (exposure to LPS), dose (concentration of LPS), and the treatment $\times$ dose were considered fixed effects. The interaction was not significant $(P>0.078)$ and was therefore removed from the model. Well (of culture plate) within animal and animal type (calf or heifer) were considered random effects. Data were analyzed for the effects of duration and dose by mean separation and using polynomial contrasts to evaluate the linear and quadratic patterns associated with duration of LPS exposure. The effect of repeated exposure to LPS (RPT) was analyzed with contrasts, comparing RPT with CON, $12 \mathrm{H}$, and RVY.

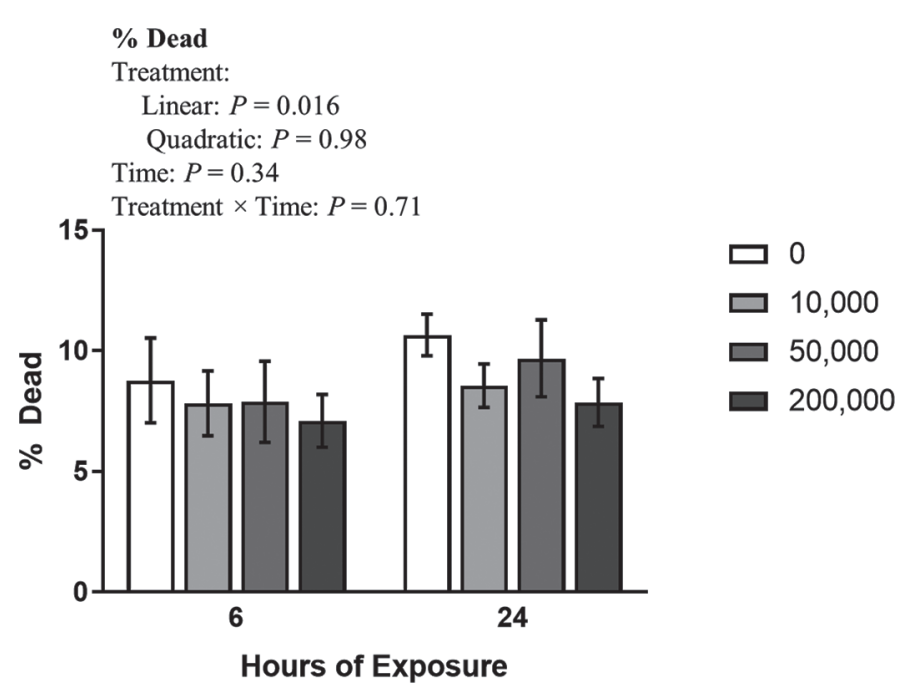

Figure 2. Percent dead of ruminal epithelial cells measured with flow cytometry when exposed to $0,10,000,50,000$, or $200,000 \mathrm{EU} / \mathrm{mL}$ LPS and following either 6 or $24 \mathrm{~h}$ of exposure. A significant $(P<$ 0.05 ) linear dose effect was observed. EU = endotoxin unit. Error bars indicate the SEM for the interaction. 
A TLR2

Treatment:

Linear: $P<0.001$

Quadratic: $P<0.001$

Time: $P=0.022$

Treatment $\times$ Time: $P<0.001$

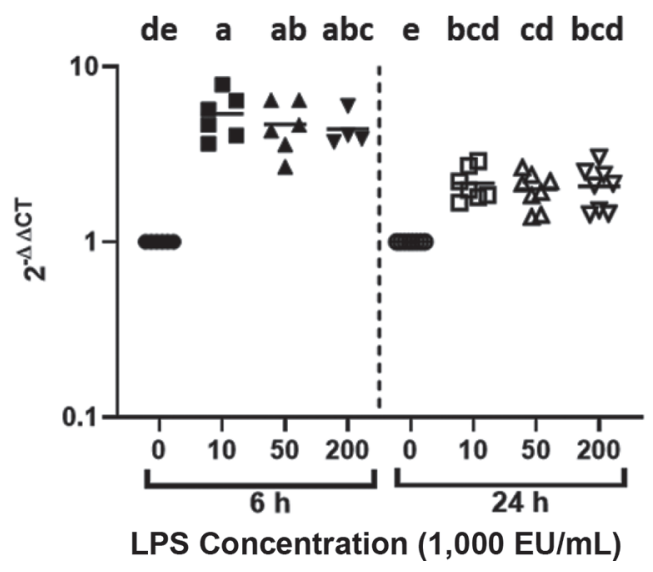

B TLR4

Treatment:

Linear: $P<0.001$

Quadratic: $P<0.001$

Time: $P=0.82$

Treatment $\times$ Time: $P<0.001$

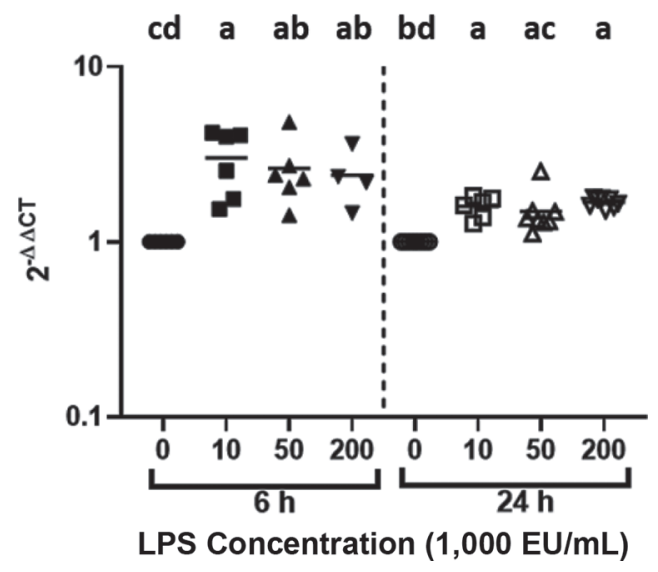

Figure 3. Expression of Toll-like receptor genes (A: TLR2; B: TLR4) in cultured ruminal epithelial cells exposed to 0 (control), 10,000, 50,000 , or $200,000 \mathrm{EU} / \mathrm{mL}$ LPS for 6 or $24 \mathrm{~h}$. Data are presented as fold change $\left(2^{-\Delta \Delta \mathrm{CT}}\right.$, where CT = cycle threshold $)$ relative to the average $\Delta \mathrm{CT}$ value for each gene in the control group. Unique letters $(\mathrm{a}-\mathrm{e})$ denote statistical significance $(P<0.05)$. EU $=$ endotoxin unit.

\section{RESULTS}

\section{Experiment 1}

There was a linear decrease $(P=0.011$; Figure 2$)$ in the percent of dead REC as LPS exposure increased from $0(9.7 \pm 0.8)$ to $200,000 \mathrm{EU} / \mathrm{mL} \operatorname{LPS}(7.5 \pm 0.8)$. No significant time $(P=0.34)$ or LPS dose $\times$ time $(P$ $=0.71)$ effects were observed.

We found treatment $\times$ time interactions for TLR2 and $T L R_{4}(P<0.001$, Figure 3$)$, with all LPS-treated groups showing higher TLR2 and TLR4 expression than their time-specific CON. The treatment $\times$ time interaction for TLR2 expression was based on greater values in REC exposed to 10,000 and $50,000 \mathrm{EU} / \mathrm{mL}$ with LPS exposure for $6 \mathrm{~h}$ (5.4- and 4.7-fold, respectively) compared with $24 \mathrm{~h}$ (2.2- and 2.0-fold, respectively). However, there was no significant $(P=0.14)$ time effect following exposure to 200,000 EU of LPS/ $\mathrm{mL}$ (Figure $3 \mathrm{~A})$. The treatment $\times$ time interaction for TLR4 (Figure 3B) did not reveal differences between TLR4 LPS individual means for each LPS concentration after 6 versus $24 \mathrm{~h}$ of exposure. However, a general trend for a greater expression of TLR 4 after $6 \mathrm{~h}$ than after $24 \mathrm{~h}$ was observed as described for TLR2.

Gene expression increased (quadratic $P<0.001$ ) in response to all doses of LPS, regardless of time, for TNF (17.5-fold, Figure 4A), IL1B (276.9-fold, Figure 4B), CXCL2 (13.9-fold Figure 4C), and CXCL8 (46.9- fold, Figure 4D), respectively. We found a treatment $\times$ time interaction for PTGS2 (Figure 5A; P $<0.001$ ), with all LPS-treated groups showing higher expression than their time-specific CON, and the magnitude of the change in expression tending to be greater at 24 h compared with $6 \mathrm{~h}$. Expression of CSF2 increased (quadratic $P<0.001$ ) in response to LPS, regardless of time (12.9- and 15.6-fold, respectively; Figure 5B). There was also a treatment $\times$ time interaction for $I L r$ (Figure $5 \mathrm{C}$ ). The expression of $I L 7$ was increased by all LPS doses over their time-specific CON; however, the expression following exposure to 10,000 and 50,000 $\mathrm{EU} / \mathrm{mL}$ was greater after $6 \mathrm{~h}$ (17.1- and 13.1-fold, respectively) compared with $24 \mathrm{~h}$ (3.7- and 4.8-fold, respectively; $P=0.003$ ).

\section{Experiment 2}

Effect of the Duration of LPS Exposure. Exposure of REC to LPS, regardless of dose, quadratically increased the expression of all genes measured, with increasing duration of exposure independent of dose $(P$ $<0.001$, Figures 6, 7, and 8). Expression of TLR4, CXCL2, and CSF2 at $24 \mathrm{H}$ was less compared with at $12 \mathrm{H}$ and $36 \mathrm{H}(P<0.001$; Figures $6 \mathrm{~B}, 7 \mathrm{C}$, and $8 \mathrm{~B}$, respectively).

Effect of Repeated LPS Exposure. For all genes except TLR 4 and $I L$ \%, expression was greater with reexposure to LPS compared with CON $(P<0.001$; Fig- 
ures 9,10 , and 11). There was a tendency for the TLR2 gene among the $12 \mathrm{H}$ and $\mathrm{RPT}$ groups $(P=0.082)$, and RPT had greater expression compared with RVY $(P$ $=0.024 ;$ Figure 9A). Expression of TLR4 (Figure 9B) was greatest when exposed to LPS for $12 \mathrm{H}$ and least for CON, RVY, and RPT $(P<0.001)$.

Expression levels of TNF, CXCL2, and CXCL8 were greater when exposed to LPS for $12 \mathrm{H}$ compared with RVY or RPT, with CON having the lowest expression $(P=0.001$, Figure 10A, C, and D) There was no differ- ence in expression of $I L 1 B$ for the $12 \mathrm{H}$ and RPT groups $(P=0.14$; Figure 10B). For TNF, IL1B, CXCL2, and $C X C L 8$, expression of RVY was greater than CON but less compared with $12 \mathrm{H}$ and RPT $(P<0.001)$

The expression of PTGS2 did not differ between $12 \mathrm{H}$ and $\operatorname{RPT}(P=0.52)$, with both being greater than CON $(P<0.001$; Figure 11A). Expression was greater after $12 \mathrm{H}$ compared with RPT for CSF2 $(P=0.011$, Figure 11B). For both PTGS2 and CSF2, RVY had greater expression than CON but was less compared
A TNF

Treatment:

Linear: $P<0.001$

Quadratic: $P<0.001$

Time: $P=0.16$

Treatment $\times$ Time: $P=0.68$

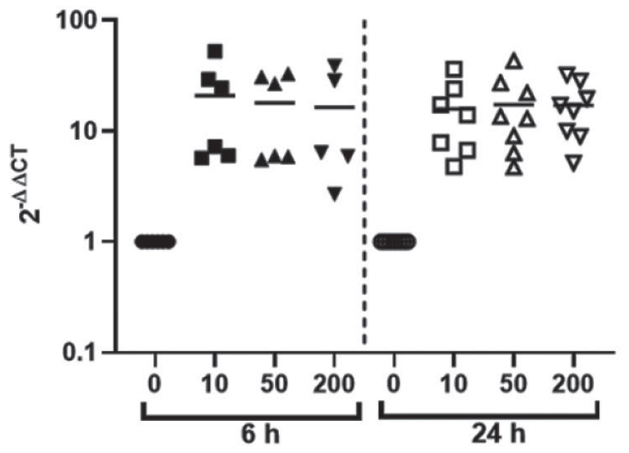

C CXCL2

Treatment:

Linear: $P<0.001$

Quadratic: $P<0.001$

Time: $P=0.83$

Treatment $\times$ Time: $P=0.74$

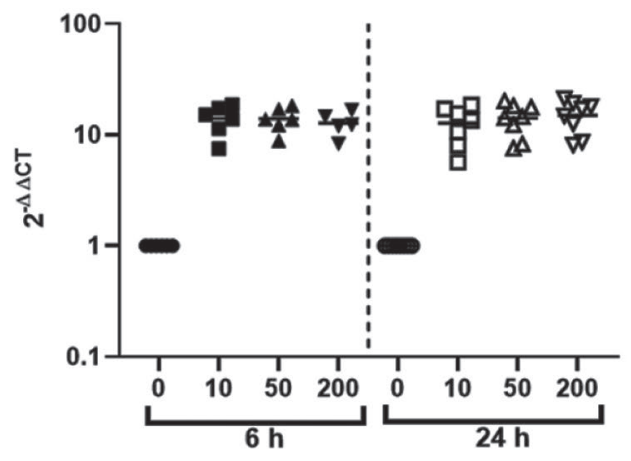

LPS Concentration $(1,000 \mathrm{EU} / \mathrm{mL})$
B IL1B

Treatment:

Linear: $P<0.001$

Quadratic: $P<0.001$

Time: $P=0.72$

Treatment $\times$ Time: $P=0.31$

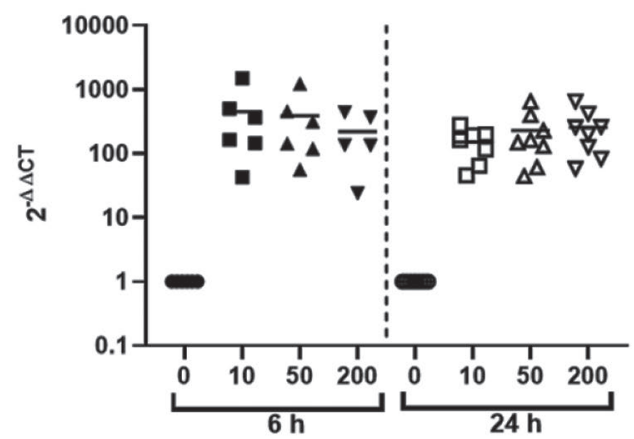

D CXCL8

Treatment:

Linear: $P<0.001$

Quadratic: $P<0.001$

Time: $P=0.18$

Treatment $\times$ Time: $P=0.35$

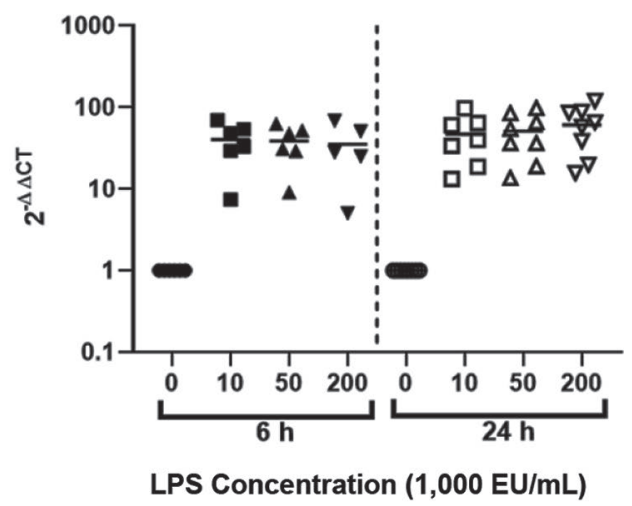

Figure 4. Expression of proinflammatory cytokine genes (A: TNF; B: IL1B) and chemokine genes (C: CXCL2; D: $C X C L 8)$ in cultured ruminal epithelial cells exposed to 0 (control), 10,000, 50,000, or 200,000 EU/mL LPS for 6 or 24 h. Data are presented as fold change ( $2^{-\Delta \Delta C T}$, where $\mathrm{CT}=$ cycle threshold) relative to the average $\Delta \mathrm{CT}$ value for each gene in the control group. $\mathrm{EU}=$ endotoxin unit. 
with $12 \mathrm{H}$ and $\mathrm{RPT}(P<0.001)$. The expression level of $I L 7$ was greatest at $12 \mathrm{H}$ compared with $\mathrm{CON}$, RVY, and $\operatorname{RPT}(P<0.001 ;$ Figure $11 \mathrm{C})$.

\section{DISCUSSION}

It is widely accepted that intestinal epithelial cells (IEC) play a direct role in gastrointestinal mucosal immunity through PRR expression and signaling that activates proinflammatory signaling pathways (Jung et al., 1995; Stadnyk, 2002; Chin et al., 2006; Hirotani et al., 2008; Kern et al., 2017). Similarly, the interaction between REC and luminal microbes or MAMP may initiate a local inflammatory response (Steele et al., 2009; Plaizier et al., 2018), but the potential for REC directly mediating these responses has not previously been well characterized.

\section{Detection of LPS by REC}

Translocation of ruminal LPS across the ruminal epithelium is thought to occur when consumption of a highly fermentable diet causes acidosis and hyperosmotic conditions in the rumen that compromise the epithelial barrier (Owens et al., 1998; Kleen et al., 2003; Khafipour et al., 2009). During the process of translocation, LPS may interact directly with REC (Emmanuel et al., 2007; Plaizier et al., 2018), affecting REC function. In fact, a dose-dependent cytotoxic effect of LPS has been reported for cultured IEC, with cell viability decreasing at an LPS concentration of $50 \mu \mathrm{g} / \mathrm{mL}$
(Chin et al., 2006). At LPS concentrations exceeding $800 \mu \mathrm{g} / \mathrm{mL}$, the viability of Caco-2 cells dropped to $30 \%$ of control cells (Hirotani et al., 2008). However, the LPS concentrations reported above are considered very high and may not be representative of physiological concentrations present in the rumen (Yagi et al., 2002; Guo et al., 2013). For the present study, a range of LPS concentrations was selected to reflect ruminal LPS concentrations reported in the literature (Plaizier et al., 2012). We observed a slight reduction in the percentage of dead cells when LPS increased from 0 to $200,000 \mathrm{EU} / \mathrm{mL}(20 \mu \mathrm{g} / \mathrm{mL})$. The reason for this increased viability is not known, but the relatively small numerical $(<3 \%)$ difference was not considered biologically relevant. Thus, our interpretation of the data was that REC exposure to moderate LPS concentrations does not have a cytotoxic effect.

Expression of PRR, such as TLR2 and TLR4 (receptors for the detection of MAMP such as LPS; Dziarski et al., 2001), has been demonstrated in ruminal epithelial tissue (Chen et al., 2012; Dionissopoulos et al., 2012; Liu et al., 2013). Indeed, mRNA for almost all mammalian toll-like receptors 1 through 10 has been detected in the ruminal epithelium of Holstein calves (Chen et al., 2012; Malmuthuge et al., 2012). However, the majority of work on inflammation in the ruminal epithelium has used whole ruminal papillae tissue (Malmuthuge et al., 2012; Liu et al., 2013; Arroyo et al., 2017) that comprised multiple cell types capable of detecting MAMP and inducing a proinflammatory response. A recent study by Kent-Dennis et al. (2019)
A PTGS2

Treatment:

Linear: $P<0.001$

Quadratic: $P<0.001$

Time: $P=0.16$

Treatment $\times$ Time: $P<0.0001$

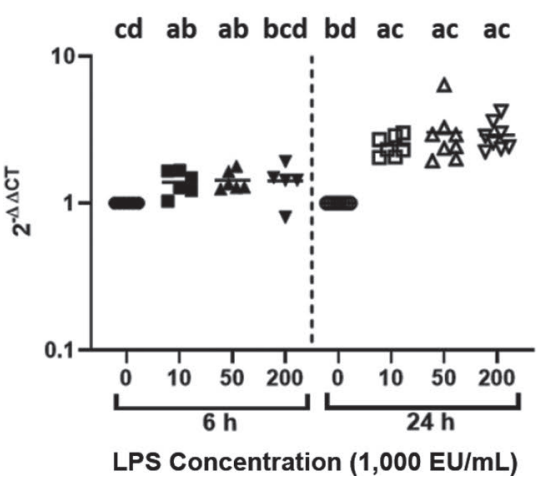

B CSF2

Treatment:

Linear: $P<0.001$

Quadratic: $P<0.001$

Time: $P=0.74$

Treatment $\times$ Time: $P=0.54$

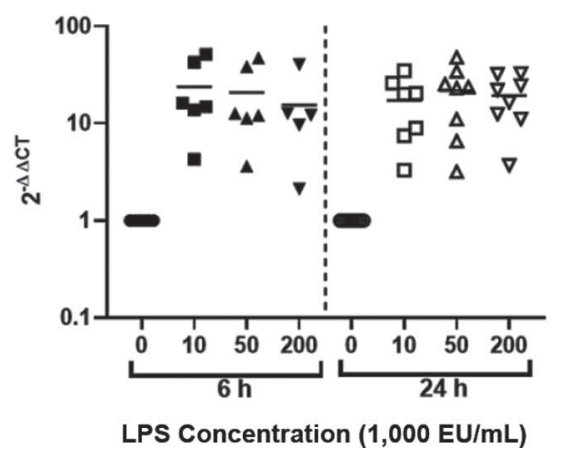

C IL 7

Treatment:

Linear: $P=0.001$

Quadratic: $P<0.001$

Time: $P=0.013$

Treatment $\times$ Time: $P=0.003$

cd a a ab a bc bc bc

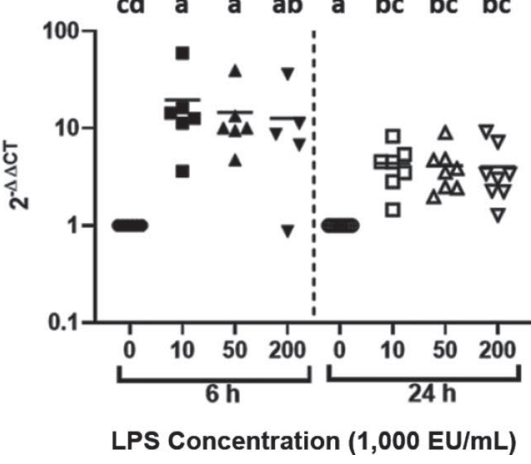

Figure 5. Expression of gene involved in generation of a lipid mediator of inflammation (A: PTGS2) and growth factor-like cytokine genes (B: CSF2; C: IL7) in cultured ruminal epithelial cells exposed to 0 (control), 10,000, 50,000, or 200,000 EU/mL LPS for 6 or 24 h. Data are presented as fold change $\left(2^{-\Delta \Delta \mathrm{CT}}\right.$, where $\mathrm{CT}=$ cycle threshold) relative to the average $\Delta \mathrm{CT}$ value for each gene in the control group. Unique letters $(\mathrm{a}-\mathrm{d})$ denote statistical significance $(P<0.05)$. EU $=$ endotoxin unit. 
A TLR2

Time:

Linear: $P<0.001$

Quadratic: $P<0.001$

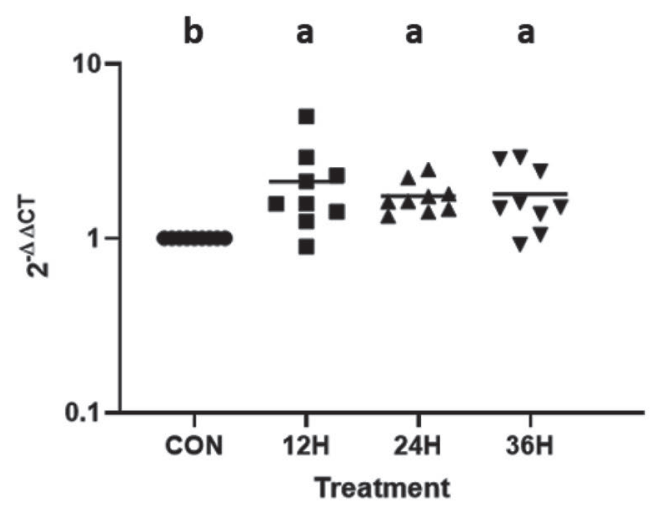

B TLR4

Time:

Linear: $P<0.001$

Quadratic: $P<0.001$

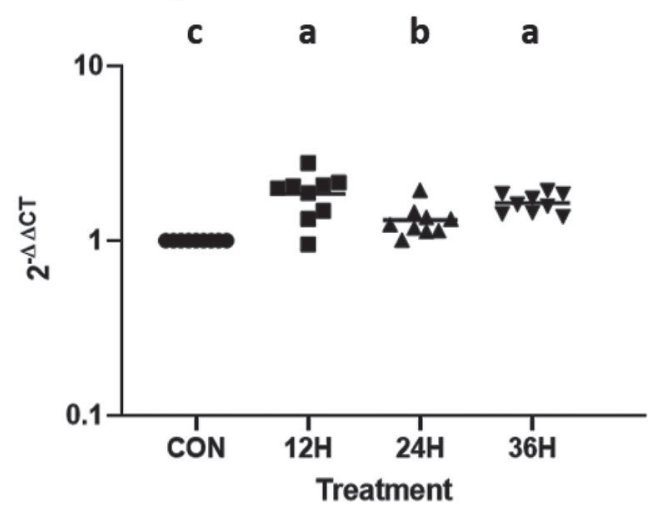

Figure 6. Time-dependent changes in gene expression of Toll-like receptors (A: TLR2; B: TLR4) in cultured ruminal epithelial cells exposed to either a low $(1,000 \mathrm{EU} / \mathrm{mL})$ or high $(50,000 \mathrm{EU} / \mathrm{mL})$ LPS dose. The dose $\times$ treatment interaction was not significant and the dose data were combined. The following treatments were compared: control (no LPS; CON), $12 \mathrm{~h}$ of LPS exposure (12H), $24 \mathrm{~h}$ of LPS exposure (24H), and 36 $\mathrm{h}$ of LPS exposure $(36 \mathrm{H})$. Data are presented as fold change $\left(2^{-\Delta \Delta \mathrm{CT}}\right.$, where $\mathrm{CT}=$ cycle threshold) relative to the average $\Delta \mathrm{CT}$ value for each gene in the control group. The dose $\times$ treatment interaction was not significant and was removed from the model. Unique letters $(\mathrm{a}-\mathrm{c})$ denote statistical significance $(P<0.05)$. EU $=$ endotoxin unit.

confirmed localization of TLR4 protein in REC, suggesting that REC alone may be capable of initiating a proinflammatory response. Supporting the previously mentioned findings, we observed that the expression of TLR 4 was upregulated when cultured REC were exposed to LPS, regardless of the concentration in experiments 1 or 2. Expression of TLR2 was also upregulated when REC were exposed to LPS, and the response to LPS was greater when measured after $6 \mathrm{H}$ compared with $24 \mathrm{H}$. The TLR2 protein has a wide variety of ligands, including LPS, which has been shown to activate TLR2 signaling (Takeuchi et al., 1999; Yang et al., 1999). Dampening of this response with longer duration of LPS exposure may serve to limit the capacity of REC to respond to LPS. This downregulation of TLR2 gene transcript may protect against potential tissue damage caused by inflammation (Lee et al., 2008). The results may also indicate that some of doses of LPS selected for this study exceeded the cells capacity to respond, (Sugimoto et al., 2016) and future research should evaluate lower exposure doses.

\section{Initiation of a Proinflammatory Response by REC}

As a result of LPS-activated TLR signaling, several proinflammatory molecules, including cytokines (Jung et al., 1995; Stadnyk, 2002), chemokines (Vallee et al., 2004; De Plaen et al., 2006), and lipid mediators of inflammation (Grishin et al., 2006; Fukata et al., 2006), are produced by nonhematopoietic cells, including IEC, during the acute phase of inflammation. A study by Liu et al. (2013) reported increased mRNA expression of proinflammatory cytokines $T N F$ and interferon gamma $(I F N G)$ in ruminal epithelia collected from goats fed a high-grain diet compared with those fed hay. Similarly, when dairy cows were fed a high-starch diet, both gene and protein expression for TLR4, IL1B, IL7, and TNF were greater compared with a low starch diet (Pan et al., 2017). Little research, however, has demonstrated a direct role for REC in initiating the local inflammatory response. Zhang et al. (2016) has reported a correlation between LPS exposure and production of proinflammatory cytokines in isolated REC. In the current study, cultured REC were exposed to LPS in a dose-dependent manner and for increasing time intervals to further characterize the REC proinflammatory response. In experiment 1 , expression of $T N F$ and $I L 1 B$ were upregulated following exposure to LPS, confirming that REC are capable of expressing proinflammatory cytokine genes. Both CXCL2 and CXCL8 were also upregulated following exposure to LPS. These chemokines are important chemo-attractants for the recruitment of leukocytes during inflammatory responses. The $C X C L 2$ gene is associated with an increased recruitment of neutrophils and mucosal lymphocytes (Ohtsuka et al., 2001), and CXCL8 is known to be a potent neutrophil recruiter and is a critical component of acute inflammation (Harada et al., 1994). The expression of TNF, 
$I L 1 B, C X C L 2$, and $C X C L 8$ was similar when REC were exposed to LPS for 6 or $24 \mathrm{~h}$, suggesting transcript abundance was maintained. Data from experiment 2 confirmed that transcript abundance for all genes remained elevated when REC were exposed to LPS for as long as $36 \mathrm{~h}$. These results suggested that REC may be directly involved in initiating a proinflammatory response in the rumen to LPS, and this REC response may be sustained for at least $36 \mathrm{~h}$. However, expression of TLR4, CXCL2, and CSF2 at $24 \mathrm{H}$ was less compared with $12 \mathrm{H}$ and $36 \mathrm{H}$, suggesting that there may have been an effect of duration of LPS exposure.

\section{A $T N F$ \\ Time:}

Linear: $P<0.001$

Quadratic: $P<0.001$

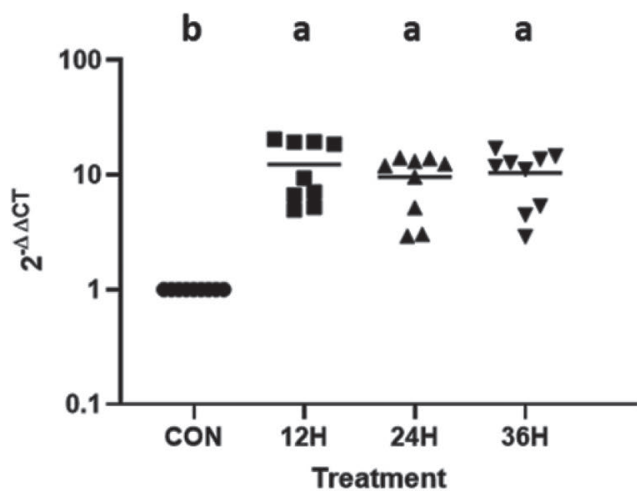

C CXCL2

Time:

Linear: $P<0.001$

Quadratic: $P<0.001$

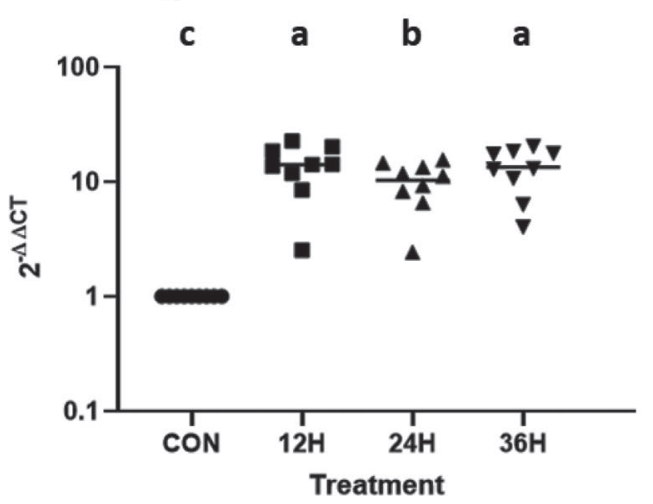

In addition, in experiment 1 we found a treatment $\times$ time interaction, where expression of PTGS2 following exposure to LPS was upregulated to a greater extent at $24 \mathrm{~h}$ than $6 \mathrm{~h}$. In experiment 2, there was a quadratic upregulation of PTGS2 with longer exposure to LPS, regardless of dose. Prostaglandins are synthesized during inflammation from arachidonic acid via 2 enzymes, PTGS1 and PTGS2 (formally known as COX1 and COX2). Whereas PTGS1 is constitutively expressed, PTGS2 is considered a proinflammatory lipid mediator of prostaglandin synthesis (Ricciotti and FitzGerald, 2011). Increased expression of PTGS2 further supports

\section{B IL1B}

Time:

Linear: $P<0.001$

Quadratic: $P<0.001$

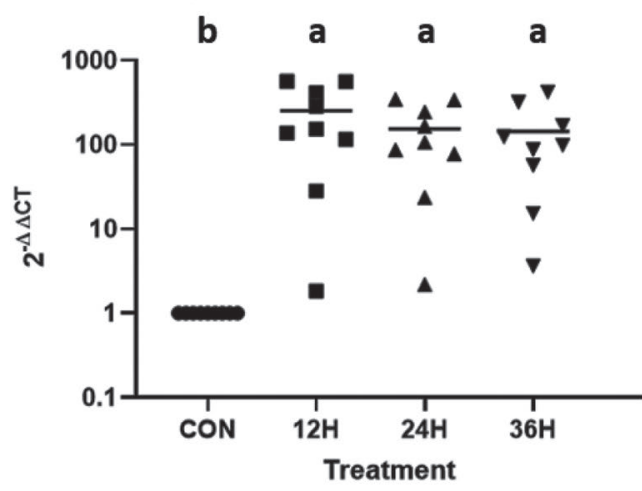

D CXCL8

Time:

Linear: $P<0.001$

Quadratic: $P<0.001$

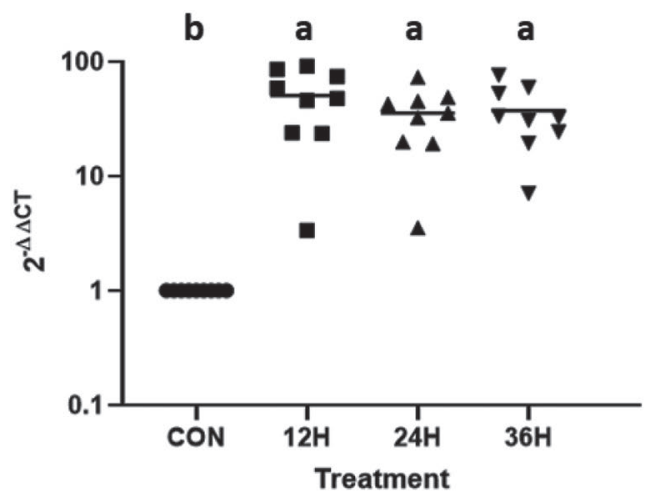

Figure 7. Time-dependent changes in gene expression of proinflammatory cytokines (A: TNF; B: IL1B) and chemokines (C: CXCL2; D: $C X C L 8)$ in cultured ruminal epithelial cells exposed to either a low $(1,000 \mathrm{EU} / \mathrm{mL})$ or high $(50,000 \mathrm{EU} / \mathrm{mL}) \mathrm{LPS}$ dose. The dose $\times$ treatment interaction was not significant and the dose data were combined. The following treatments were compared: control (no LPS; CON), $12 \mathrm{~h}$ of LPS exposure $(12 \mathrm{H}), 24 \mathrm{~h}$ of LPS exposure $(24 \mathrm{H})$, and $36 \mathrm{~h}$ of LPS exposure $(36 \mathrm{H})$. Data are presented as fold change $\left(2^{-\Delta \Delta \mathrm{CT}}\right.$, where $\mathrm{CT}=\mathrm{cycle}$ threshold) relative to the average $\Delta \mathrm{CT}$ value for each gene in the control group. The dose $\times$ treatment interaction was not significant and was removed from the model. Unique letters $(\mathrm{a}-\mathrm{c})$ denote statistical significance $(P<0.05)$. EU $=$ endotoxin unit. 
A PTGS2

Time:

Linear: $P<0.001$

Quadratic: $P<0.001$

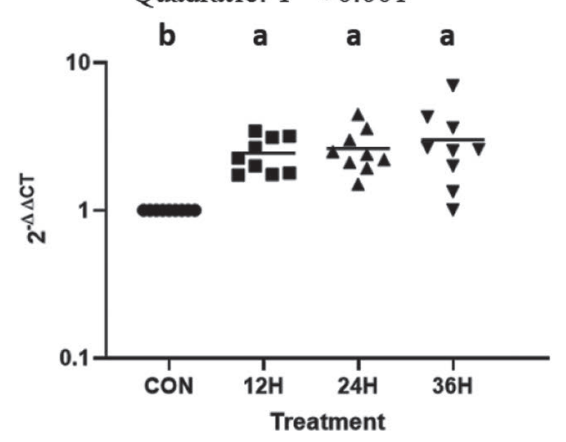

B CSF2

Time:

Linear: $P<0.001$

Quadratic: $P<0.001$

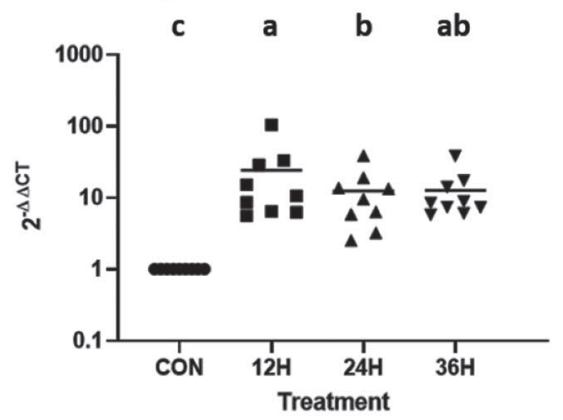

C $\quad$ IL 7

Time:

Linear: $P=0.007$

Quadratic: $P<0.001$

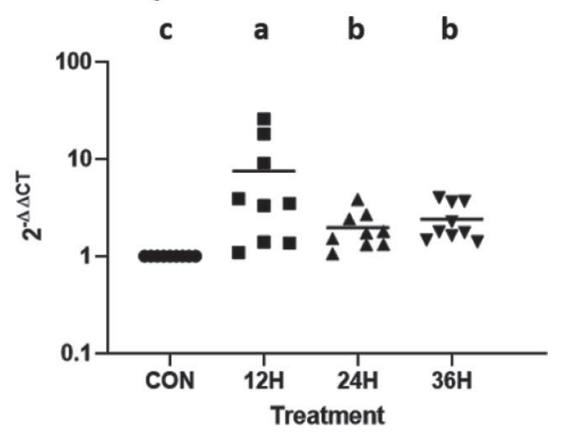

Figure 8. Time-dependent changes in gene expression of lipid mediator of inflammation (A: PTGS2) and growth factor-like cytokines (B: CSF2; C: $I L 7)$ in cultured ruminal epithelial cells exposed to either a low $(1,000 \mathrm{EU} / \mathrm{mL})$ or high $(50,000 \mathrm{EU} / \mathrm{mL}) \mathrm{LPS}$ dose. The dose $\times$ treatment interaction was not significant and the dose data were combined. The following treatments were compared: control (no LPS; CON), $12 \mathrm{~h}$ of LPS exposure $(12 \mathrm{H}), 24 \mathrm{~h}$ of LPS exposure $(24 \mathrm{H})$, and $36 \mathrm{~h}$ of LPS exposure $(36 \mathrm{H})$. Data are presented as fold change $\left(2^{-\Delta \Delta \mathrm{CT}}\right.$, where CT $=$ cycle threshold) relative to the average $\Delta \mathrm{CT}$ value for each gene in the control group. The dose $\times$ treatment interaction was not significant and was removed from the model. Unique letters $(\mathrm{a}-\mathrm{c})$ denote statistical significance $(P<0.05)$. $\mathrm{EU}=$ endotoxin unit.

the conclusion that REC may play a role in initiating inflammation in the ruminal epithelium.

Intestinal epithelial cells are involved in coordinating crosstalk with immune cells, such as resident dendritic cells (Loss et al., 2018, 2019), intraepithelial lymphocytes, and lamina propria $\mathrm{T}$ and $\mathrm{B}$ lymphocytes (Clark and Coopersmith, 2007; Hooper, 2015). During acute inflammation, IEC have been shown to produce molecules that promote and regulate immune cell functions (Hooper, 2015). To further explore this role in REC, 2 growth factor-like cytokines, CSF2 and IL7, were selected in this study. Colony-stimulating factor-2 is expressed by many cell types, including IEC during inflammation (Egea et al., 2013), and promotes differentiation and survival of myeloid cells, especially tissue-resident mononuclear phagocytes (Mortha et al., 2014). Production of CSF2 by colonic epithelial cells has been reported to play a role in epithelial cell repair and recovery following induction of colitis (Egea et al., 2013). In the present study, CSF2 was expressed in REC at significantly greater levels when cells were exposed to LPS compared with CON, regardless of LPS

\section{A TLR2}

Treatment: $P<0.001$

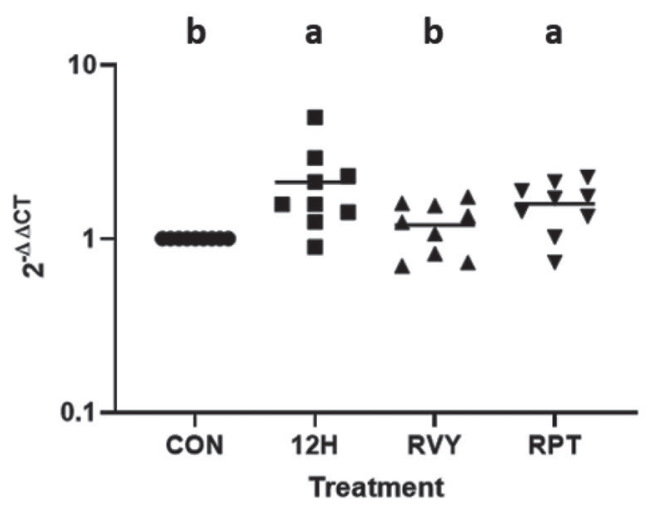

B TLR4

Treatment: $P<0.001$

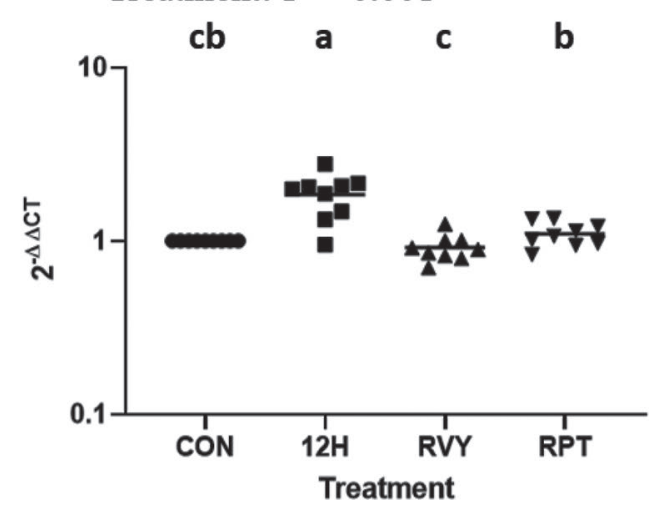

Figure 9. Expression of Toll-like receptor genes (A: TLR2; B: TLR4) in cultured ruminal epithelial cells exposed to either a low (1,000 EU/ $\mathrm{mL})$ or high $(50,000 \mathrm{EU} / \mathrm{mL})$ LPS dose. The dose $\times$ treatment interaction was not significant and the dose data were combined. The following treatments were compared: control (no LPS; CON), $12 \mathrm{~h}$ of LPS exposure (12H), $12 \mathrm{~h}$ of LPS exposure followed by $36 \mathrm{~h}$ of no exposure (RVY), and $12 \mathrm{~h}$ of LPS exposure followed by $24 \mathrm{~h}$ of no exposure followed by another $12 \mathrm{~h}$ of exposure (RPT). Data are presented as fold change $\left(2^{-\Delta \Delta \mathrm{CT}}\right.$, where $\mathrm{CT}=$ cycle threshold $)$ relative to the average $\Delta \mathrm{CT}$ value for each gene in the control group. The dose $\times$ treatment interaction was not significant and was removed from the model. Unique letters $(\mathrm{a}-\mathrm{c})$ denote statistical significance $(P<0.05)$. EU $=$ endotoxin unit. 
A $T N F$

Treatment: $P<0.001$

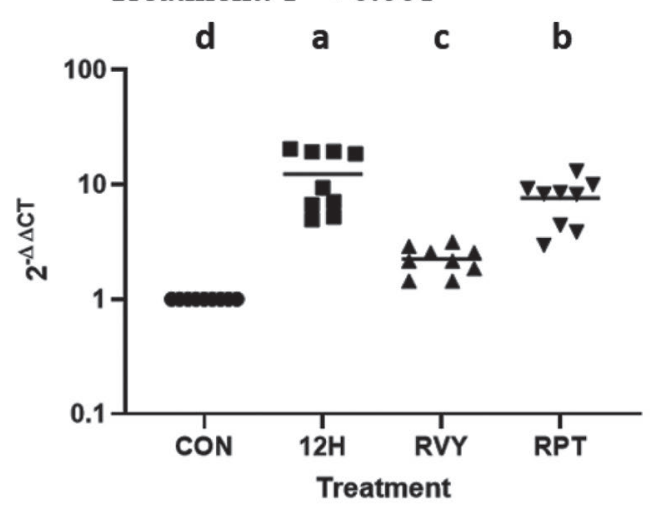

C CXCL2

Treatment: $P<0.001$

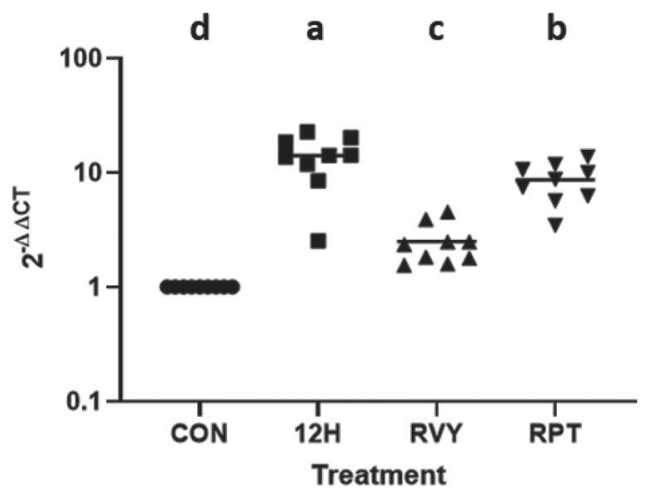

B ILIB

Treatment: $P<0.001$

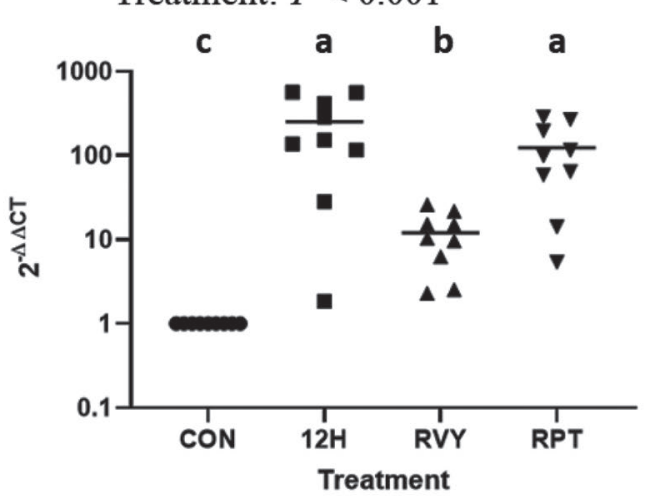

D CXCLS

Treatment: $P<0.001$

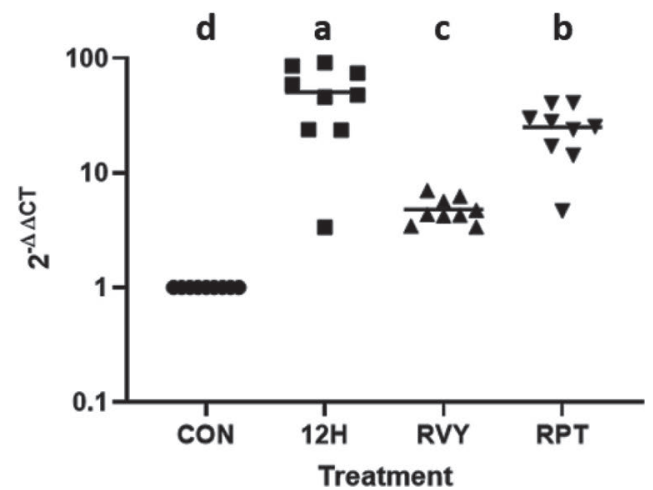

Figure 10. Gene expression of proinflammatory cytokines (A: TNF; B: IL1B) and chemokines (C: CXCL2; D: CXCL8) in cultured ruminal epithelial cells exposed to either a low $(1,000 \mathrm{EU} / \mathrm{mL})$ or high $(50,000 \mathrm{EU} / \mathrm{mL})$ LPS dose. The dose $\times$ treatment interaction was not significant and the dose data were combined. The following treatments were compared: control (no LPS; CON), $12 \mathrm{~h}$ of LPS exposure (12H), $12 \mathrm{~h}$ of LPS exposure followed by $36 \mathrm{~h}$ of no exposure (RVY), and $12 \mathrm{~h}$ of LPS exposure followed by $24 \mathrm{~h}$ of no exposure followed by another $12 \mathrm{~h}$ of exposure (RPT). Data are presented as fold change $\left(2^{-\Delta \Delta \mathrm{CT}}\right.$, where $\mathrm{CT}=$ cycle threshold) relative to the average $\Delta \mathrm{CT}$ value for each gene in the control group. The dose $\times$ treatment interaction was not significant and was removed from the model. Unique letters (a-d) denote statistical significance $(P<0.05)$. EU $=$ endotoxin unit.

concentration and exposure time, suggesting the function of CSF2 in REC may be similar to that in IEC.

The growth factor-like cytokine IL7 is critical for development and survival of $\mathrm{T}$ and $\mathrm{B}$ lymphocytes (Mackall et al., 2011). It is mainly produced by nonhematopoietic stromal cells (Mackall et al., 2011), but IEC have also been shown to produce IL7 in response to infection (Zhang et al., 2015). In the intestinal epithelia, elevated levels of IL7 may be important for the regulation of tissue-resident lymphocyte function (Watanabe et al., 1995). In experiment 1 of the present study, IL7 was upregulated when REC were exposed to LPS; however, expression was less after $24 \mathrm{~h}$ of exposure compared with $6 \mathrm{~h}$, with more than a 5 -fold difference. Further, results from experiment 2 showed that expression of $I L 7$ decreased when duration of exposure was increased to 24 and $36 \mathrm{~h}$. These results suggest that $I L 7$ may be involved in the acute phase of inflammation but is tightly regulated. Indeed, previous work has shown evidence for stringent regulation of $I L 7$ production and expression of the $I L 7$ receptor, which may control proliferation of $\mathrm{T}$ cells and epithelial cells (Mackall et al., 2011). Expression of $I L 7$ by REC may have similar feedback mechanisms. The expression patterns of $I L 7$ and CSF2 observed in the present study suggest that the rumen epithelial mucosa may interact with either infiltrating or tissue-resident immune cells (Steele et al., 2009; Trevisi et al., 2014).

\section{Tolerance of REC to LPS}

An important regulatory mechanism for epithelial cells in the gastrointestinal tract is the development of dampened responses to luminal MAMP and other 
antigens to reduce tissue damage by proinflammatory molecules (Chistiakov et al., 2015). Endotoxin tolerance has been reported in IEC (Lotz et al., 2007; Lee et al., 2008), and previous studies have suggested that repeated exposure to LPS reduces the magnitude of the proinflammatory response (Nomura et al., 2000; Beutler and Rietschel, 2003). The concept of endotoxin tolerance has also been explored in mucosal surfaces of ruminants (Bieniek et al., 1998; Petzl et al., 2011; Gott et al., 2015). Despite the fact that the REC may have multiple exposures to ruminal LPS during their progression from stratum basale to the stratum granulosum, and finally the stratum corneum, endotoxin tolerance has not been previously evaluated in the ruminal epithelium. In experiment 2, when REC were exposed to a single dose of LPS for $12 \mathrm{~h}$, regardless of concentration, expression of all genes was increased, suggesting a rapid, proinflammatory response to LPS by the REC. Following a period without LPS exposure, REC were exposed to a second 12-h dose of LPS. Although there was still an increase in expression of most genes evaluated compared with $\mathrm{CON}$, the second dose of LPS resulted in lower fold changes for TLR4, TNF, CXCL2, CXCL8, CSF2, and IL7 compared with a first $12 \mathrm{~h}$ of LPS exposure.

These results suggest a dampening of proinflammatory gene expression in REC following repeated or prolonged exposures to LPS. In previous work, pretreatment with LPS was administered, and a decreased response to subsequent LPS exposure was apparent with decreased expression of classical proinflammatory cytokines (Harada et al., 1994). In agreement with these results, an in vivo study by Petzl et al. (2011) observed decreased mRNA abundance for TNF and $C X C L 8$ when an intramammary pretreatment with LPS was given before a bacterial challenge. Additionally, prolonged LPS exposure is associated with endotoxin tolerance in a variety of cells types and tissues (Seeley and Ghosh, 2017). In support, a continuous dose of TNF infused into adipose tissue of dairy cows resulted in a suppressed inflammatory response, suggesting that proinflammatory cytokines may also have a tolerogenic effect (Martel et al., 2014).

In the present experiment, expression of CSF2 was less when the REC were restimulated compared with $12 \mathrm{H}$. Expression of CSF2 is closely associated with $T N F$ expression and may be important in regulating acute inflammation by modulating proinflammatory cytokines and chemokines production (Nierhaus et al., 2017). Moreover, IL 7 did not appear to respond at all to the second dose, as its expression in the RPT group was the same as the control. A study by Julian et al. (2015) demonstrated that IL7 is involved in immune tolerance and may be important for reversing tolerance in splenocytes, suggesting that IL7 helps to promote and restore $\mathrm{T}$ cell function.

Expression of $I L 1 B$ following the second LPS exposure was similar to that of the initial response. The reason for this effect is unknown; however, previous work has shown that circulating $I L 1 B$ has a positive feedback effect on itself (Dinarello et al., 2000) and also that other proinflammatory cytokines can sustain $I L 1 B$ expression for more than $24 \mathrm{~h}$ (Schindler et al., 1990). Following the second LPS exposure, expression of TLR2 was also similar to that of the initial response. Considering the expression of TLR2 in experiment 1,
A PTGS2

Treatment: $P<0.001$

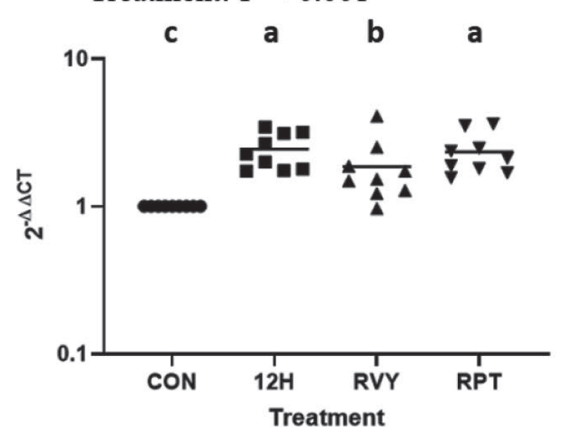

B CSF2

Treatment: $P<0.001$

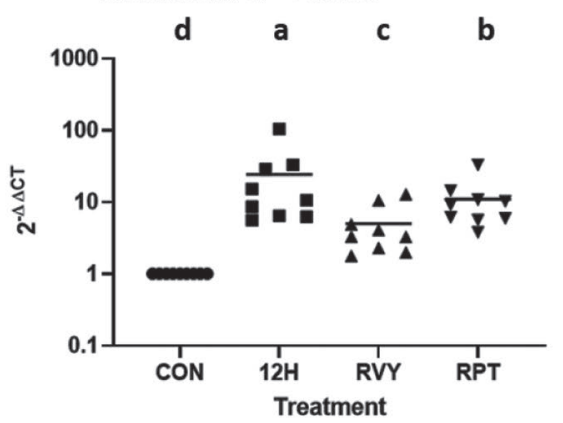

C $\quad$ IL 7

Treatment: $P<0.001$

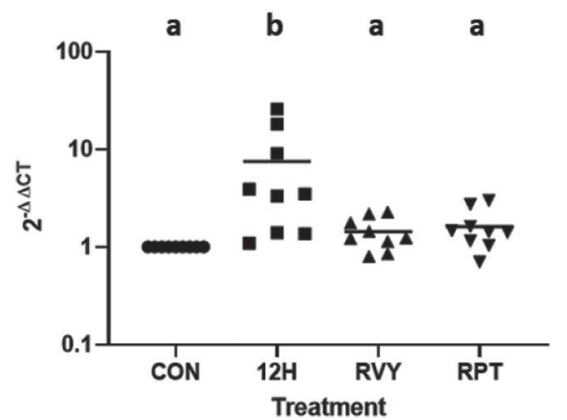

Figure 11. Gene expression of lipid mediator of inflammation (A: PTGS2) and growth factor-like cytokines (B: CSF2; C: IL7) in cultured ruminal epithelial cells exposed to either a low $(1,000 \mathrm{EU} / \mathrm{mL})$ or high $(50,000 \mathrm{EU} / \mathrm{mL})$ LPS dose. The dose $\times$ treatment interaction was not significant and the dose data were combined. The following treatments were compared: control (no LPS; CON), $12 \mathrm{~h}$ of LPS exposure (12H), $12 \mathrm{~h}$ of LPS exposure followed by $36 \mathrm{~h}$ of no exposure (RVY), and $12 \mathrm{~h}$ of LPS exposure followed by $24 \mathrm{~h}$ of no exposure followed by another $12 \mathrm{~h}$ of exposure (RPT). Data are presented as fold change $\left(2^{-\Delta \Delta \mathrm{CT}}\right.$, where $\mathrm{CT}=$ cycle threshold $)$ relative to the average $\Delta \mathrm{CT}$ value for each gene in the control group. The dose $\times$ treatment interaction was not significant and was removed from the model. Unique letters (a-d) denote statistical significance $(P<0.05)$. EU $=$ endotoxin unit. 
results suggest that TLR2 signaling in REC may be influenced more by LPS dose or duration rather than repeated LPS exposure.

In experiment 2, when LPS was removed from the media (RVY), the expression of all genes measured was decreased significantly $36 \mathrm{~h}$ after exposure compared with only $12 \mathrm{~h}$ of LPS exposure. In addition, TLR2, $T L R 4$, and $I L 7$ expression levels returned to baseline. These data suggest that although moderate exposure of LPS to ruminal epithelium induces a proinflammatory response, the effects are not sustained if the exposure is limited. However, TNF, IL1B, CXCL2, CXCL8, PTGS2, and CSF2 were all significantly upregulated compared with the control. These results demonstrated that the REC were able to recover after the LPS exposure, although there was still expression of some of the proinflammatory genes even after the LPS had been removed, suggesting that some residual transcription occurred.

The method in this study used cultured REC primarily derived from the stratum basale and stratum spinosum layers of the ruminal epithelium (Gálfi et al., 1980). Under acidotic conditions in vivo, these cells may become exposed to microbes or MAMP as a consequence of a compromised epithelial barrier (Aschenbach et al., 2019). The present results demonstrated that in vitro exposure to LPS stimulated a proinflammatory response. As with all cell culture, however, there were limitations to the current model. For example, complex interactions with other cell types, such as immune cells, may influence the response (Freshney, 2010). In addition, the most basal layers of cells may respond differently from those of the more luminal layers (KentDennis et al., 2019). Therefore, a monolayer of REC in culture may not be entirely representative of the effects in vivo with a heterogeneous population of cells. Additionally, this study used a transcriptomic approach alone with a few carefully selected genes to evaluate the inflammatory responses in REC. Further work to assess these responses from a broader transcriptomic level coupled with protein expression may bolster the understanding of the effects of LPS exposure. With these limitations in mind, the present study provided novel insight into the specific response of the REC when exposed to LPS.

\section{CONCLUSIONS}

Previous research has provided evidence for a local inflammatory response in ruminal papillae, presumably a consequence of translocation of microbes or MAMP during ruminal acidosis. Our data provide conclusive evidence that REC have the capacity to play a direct role in initiating proinflammatory responses when exposed to LPS. Moreover, the results of the present study suggest that when REC are repeatedly exposed to LPS, there is a dampened expression of some proinflammatory genes, suggesting a potential tolerogenic response. Finally, following LPS induction of a proinflammatory gene response, REC are able to recover, but increased expression of some proinflammatory genes may remain elevated for at least $36 \mathrm{~h}$ after the LPS is removed. Overall, our results suggest that the REC response to LPS is dependent on several exposure conditions, such as LPS dose, duration of LPS exposure, and frequency of LPS stimulation.

\section{ACKNOWLEDGMENTS}

Funding support for the project was provided by the National Science and Engineering Research Council of Canada (Ottawa, ON, Canada), the Centennial Enhancement Chair Fund from the University of the Saskatchewan (Saskatoon, SK, Canada), and by a Tier I CRC in Neonatal Mucosal Immunology provided by Canada Institutes for Health Research (CIHR; Ottawa, ON, Canada). The authors have not stated any conflicts of interest.

\section{REFERENCES}

Arroyo, J. M., A. Hosseini, Z. Zhou, A. Alharthi, E. Trevisi, J. S. Osorio, and J. J. Loor. 2017. Reticulo-rumen mass, epithelium gene expression, and systemic biomarkers of metabolism and inflammation in Holstein dairy cows fed a high-energy diet. J. Dairy Sci. 100:9352-9360. https://doi.org/10.3168/jds.2017-12866.

Aschenbach, J. R., and G. Gabel. 2000. Effect and absorption of histamine in sheep rumen: Significance of acidotic epithelial damage. J. Anim. Sci. 78:464-470. https://doi.org/10.2527/2000.782464x.

Aschenbach, J. R., Q. Zebeli, A. K. Patra, G. Greco, S. Amasheh, and G. B. Penner. 2019. Symposium review: The importance of the ruminal epithelial barrier for a healthy and productive cow. J. Dairy Sci. 102:1866-1882. https://doi.org/10.3168/jds.2018-15243.

Beutler, B., and E. T. Rietschel. 2003. Innate immune sensing and its roots: The story of endotoxin. Nat. Rev. Immunol. 3:169-176. https://doi.org/10.1038/nri1004.

Bieniek, K., A. Szuster-Ciesielska, T. Kaminska, M. Kondracki, M. Witek, and M. Kandefer-Szerszen. 1998. Tumor necrosis factor and interferon activity in the circulation of calves after repeated injection of low doses of lipopolysaccharide. Vet. Immunol. Immunopathol. 62:297-307. https://doi.org/10.1016/S0165-2427(98)00102 -0 .

Chen, Y., M. Oba, and L. L. Guan. 2012. Variation of bacterial communities and expression of Toll-like receptor genes in the rumen of steers differing in susceptibility to subacute ruminal acidosis. Vet. Microbiol. 159:451-459. https://doi.org/10.1016/j.vetmic.2012.04 .032 .

Chin, A. C., A. N. Flynn, J. P. Fedwick, and A. G. Buret. 2006. The role of caspase-3 in lipopolysaccharide-mediated disruption of intestinal epithelial tight junctions. Can. J. Physiol. Pharmacol. 84:1043-1050. https://doi.org/10.1139/y06-056.

Chistiakov, D. A., Y. V. Bobryshev, E. Kozarov, I. A. Sobenin, and A. N. Orekhov. 2015. Intestinal mucosal tolerance and impact of gut 
microbiota to mucosal tolerance. Front. Microbiol. 5:781. https:// doi.org/10.3389/fmicb.2014.00781.

Clark, J. A., and C. M. Coopersmith. 2007. Intestinal crosstalk: A new paradigm for understanding the gut as the "motor" of critical illness. Shock 28:384-393. https://doi.org/10.1097/shk .0b013e31805569df.

De Plaen, I. G., X. B. Han, X. Liu, W. Hsueh, S. Ghosh, and M. J. May. 2006. Lipopolysaccharide induces CXCL2/macrophage inflammatory protein-2 gene expression in enterocytes via NF-kap$\mathrm{paB}$ activation: Independence from endogenous TNF-alpha and platelet-activating factor. Immunology 118:153-163. https://doi .org/10.1111/j.1365-2567.2006.02344.x.

Dinarello, C. A. 2000. Proinflammatory cytokines. Chest 118:503-508. https://doi.org/10.1378/chest.118.2.503.

Dionissopoulos, L., M. A. Steele, O. AlZahal, J. C. Plaizier, and B. W. McBride. 2012. A characterization of inflammatory and structural markers within the rumen epithelium during grain-induced ruminal acidosis in lactating dairy cattle. Am. J. Anim. Vet. Sci. 7:141-148. https://doi.org/10.3844/ajavsp.2012.141.148.

Dziarski, R., Q. Wang, K. Miyake, C. J. Kirschning, and D. Gupta. 2001. MD-2 enables Toll-like receptor 2 (TLR2)-mediated responses to lipopolysaccharide and enhances TLR2-mediated responses to Gram-positive and Gram-negative bacteria and their cell wall components. J. Immunol. 166:1938-1944. https://doi.org/10.4049/ jimmunol.166.3.1938.

Egea, L., C. S. McAllister, O. Lakhdari, I. Minev, S. Shenouda, and M. F. Kagnoff. 2013. GM-CSF produced by nonhematopoietic cells is required for early epithelial cell proliferation and repair of injured colonic mucosa. J. Immunol. 190:1702-1713. https://doi.org/10 .4049/jimmunol.1202368.

Emmanuel, D. G., K. L. Madsen, T. A. Churchill, S. M. Dunn, and B. N. Ametaj. 2007. Acidosis and lipopolysaccharide from Escherichia coli B:055 cause hyperpermeability of rumen and colon tissues. J. Dairy Sci. 90:5552-5557. https://doi.org/10.3168/jds .2007-0257.

Freshney, R. I. 2010. Primary culture. Pages 163-186 in Culture of Animal Cells: A Manual of Basic Technique and Specialized Applications. 6th ed. John Wiley \& Sons Inc., Hoboken, NJ.

Fukata, M., A. Chen, A. Klepper, S. Krishnareddy, A. S. Vamadevan, L. S. Thomas, R. Xu, H. Inoue, M. Arditi, A. J. Dannenberg, and M. T. Abreu. 2006. Cox-2 is regulated by Toll-like receptor-4 (TLR4) signaling: Role in proliferation and apoptosis in the intestine. Gastroenterology 131:862-877. https://doi.org/10.1053/j .gastro.2006.06.017.

Gálfi, P., S. Neogrady, and F. Kutas. 1980. Culture of epithelial cells from bovine ruminal mucosa. Vet. Res. Commun. 4:295-300. https: //doi.org/10.1007/BF02278507.

Gott, P. N., J. S. Hogan, and W. P. Weiss. 2015. Effects of various starch feeding regimens on responses of dairy cows to intramammary lipopolysaccharide infusion. J. Dairy Sci. 98:1786-1796. https://doi.org/10.3168/jds.2014-8638.

Grishin, A. V., J. Wang, D. A. Potoka, D. J. Hackam, J. S. Upperman, P. Boyle, R. Zamora, and H. R. Ford. 2006. Lipopolysaccharide induces cyclooxygenase-2 in intestinal epithelium via a noncanonical p38 MAPK pathway. J. Immunol. 176:580-588. https://doi.org/10 .4049/jimmunol.176.1.580.

Guo, S., R. Al-Sadi, H. M. Said, and T. Y. Ma. 2013. Lipopolysaccharide causes an increase in intestinal tight junction permeability in vitro and in vivo by inducing enterocyte membrane expression and localization of TLR-4 and CD14. Am. J. Pathol. 182:375-387. https://doi.org/10.1016/j.ajpath.2012.10.014.

Harada, A., N. Sekido, T. Akahoshi, T. Wada, N. Mukaida, and K. Matsushima. 1994. Essential involvement of interleukin-8 (IL-8) in acute inflammation. J. Leukoc. Biol. 56:559-564. https://doi.org/ 10.1002/jlb.56.5.559.

Hirotani, Y., K. Ikeda, R. Kato, M. Myotoku, T. Umeda, Y. Ijiri, and K. Tanaka. 2008. Protective effects of lactoferrin against intestinal mucosal damage induced by lipopolysaccharide in human intestinal Caco-2 cells. Yakugaku Zasshi 128:1363-1368. https://doi.org/ 10.1248/yakushi.128.1363.
Hooper, L. V. 2015. Epithelial cell contributions to intestinal immunity. Adv. Immunol. 126:129-172. https://doi.org/10.1016/bs.ai .2014.11.003.

Julian, M. W., H. R. Strange, M. N. Ballinger, R. S. Hotchkiss, T. L. Papenfuss, and E. D. Crouser. 2015. Tolerance and cross-tolerance following Toll-like receptor (TLR)-4 and -9 activation are mediated by IRAK-M and modulated by IL-7 in murine splenocytes. PLoS One 10:e0132921. https://doi.org/10.1371/journal.pone.0132921.

Jung, H. C., L. Eckmann, S. K. Yang, A. Panja, J. Fierer, E. Morzycka-Wroblewska, and M. F. Kagnoff. 1995. A distinct array of proinflammatory cytokines is expressed in human colon epithelial cells in response to bacterial invasion. J. Clin. Invest. 95:55-65. https:/ /doi.org/10.1172/JCI117676.

Kent-Dennis, C., A. Pasternak, J. C. Plaizier, and G. B. Penner. 2019. Potential for a localized immune response by the ruminal epithelium in nonpregnant heifers following a short-term subacute ruminal acidosis challenge. J. Dairy Sci. 102:7556-7569. https://doi .org/10.3168/jds.2019-16294.

Kern, M., D. Günzel, J. R. Aschenbach, K. Tedin, A. Bondzio, and U. Lodemann. 2017. Altered cytokine expression and barrier properties after in vitro infection of porcine epithelial cells with enterotoxigenic Escherichia coli and probiotic Enterococcus faecium. Mediators Inflamm. 2017:2748192. https://doi.org/10.1155/2017/ 2748192.

Khafipour, E., D. O. Krause, and J. C. Plaizier. 2009. A grain-based subacute ruminal acidosis challenge causes translocation of lipopolysaccharide and triggers inflammation. J. Dairy Sci. 92:10601070. https://doi.org/10.3168/jds.2008-1389.

Kisselbach, L., M. Merges, A. Bossie, and A. Boyd. 2009. CD90 Expression on human primary cells and elimination of contaminating fibroblasts from cell cultures. Cytotechnology 59:31-44. https:// doi.org/10.1007/s10616-009-9190-3.

Kleen, J. L., G. A. Hooijer, J. Rehage, and J. P. Noordhuizen. 2003 Subacute ruminal acidosis (SARA): A review. J. Vet. Med. A Physiol. Pathol. Clin. Med. 50:406-414. https://doi.org/10.1046/j .1439-0442.2003.00569.x

Lee, J., J. M. Gonzales-Navajas, and E. Raz. 2008. The "polarizingtolerizing" mechanism of intestinal epithelium: Its relevance to colonic homeostasis. Semin. Immunopathol. 30:3-9. https://doi.org/ 10.1007/s00281-007-0099-7.

Li, S., E. Khafipour, D. O. Krause, A. Kroeker, J. C. RodriguezLecompte, G. N. Gozho, and J. C. Plaizier. 2012. Effects of subacute ruminal acidosis challenges on fermentation and endotoxins in the rumen and hindgut of dairy cows. J. Dairy Sci. 95:294-303. https://doi.org/10.3168/jds.2011-4447.

Liu, J. H., T. T. Xu, Y. J. Liu, W. Y. Zhu, and S. Y. Mao. 2013. A high-grain diet causes massive disruption of ruminal epithelial tight junctions in goats. Am. J. Physiol. Regul. Integr. Comp. Physiol. 305:R232-R241. https://doi.org/10.1152/ajpregu.00068 2013.

Loerch, S. C. 1990. Effects of feeding growing cattle high-concentrate diets at a restricted intake on feedlot performance. J. Anim. Sci. 68:3086-3095. https://doi.org/10.2527/1990.68103086x.

Loss, H., J. R. Aschenbach, F. Ebner, K. Tedin, and U. Lodemann. 2019. Inflammatory responses of porcine MoDC and intestinal epithelial cells in a direct-contact co-culture system following a bacterial challenge. Inflammation. https://doi.org/10.1007/s10753 -019-01137-4.

Loss, H., J. R. Aschenbach, K. Tedin, F. Ebner, and U. Lodemann. 2018. The inflammatory response to enterotoxigenic E. coli and probiotic E. faecium in a coculture model of porcine intestinal epithelial and dendritic cells. Mediators Inflamm. 2018:9368295. https://doi.org/10.1155/2018/9368295.

Lotz, M., T. Konig, S. Menard, D. Gutle, C. Bogdan, and M. W. Hornef. 2007. Cytokine-mediated control of lipopolysaccharideinduced activation of small intestinal epithelial cells. Immunology 122:306-315. https://doi.org/10.1111/j.1365-2567.2007.02639.x.

Mackall, C. L., T. J. Fry, and R. E. Gress. 2011. Harnessing the biology of IL-7 for therapeutic application. Nat. Rev. Immunol. 11:330-342. https://doi.org/10.1038/nri2970. 
Malmuthuge, N., M. Li, P. Fries, P. J. Griebel, and L. L. Guan. 2012. Regional and age dependent changes in gene expression of Tolllike receptors and key antimicrobial defence molecules throughout the gastrointestinal tract of dairy calves. Vet. Immunol. Immunopathol. 146:18-26. https://doi.org/10.1016/j.vetimm.2012.01.010.

Martel, C. A., L. K. Mamedova, J. E. Minton, M. L. Jones, J. A. Carroll, and B. J. Bradford. 2014. Continuous low-dose infusion of tumor necrosis factor alpha in adipose tissue elevates adipose tissue interleukin 10 abundance and fails to alter metabolism in lactating dairy cows. J. Dairy Sci. 97:4897-4906. https://doi.org/ 10.3168/jds.2013-7777.

Meissner, S., F. Hagen, C. Deiner, D. Gunzel, G. Greco, Z. Shen, and J. R. Aschenbach. 2017. Key role of short-chain fatty acids in epithelial barrier failure during ruminal acidosis. J. Dairy Sci. 100:6662-6675. https://doi.org/10.3168/jds.2016-12262.

Minuti, A., A. Palladino, M. J. Khan, S. Alqarni, A. Agrawal, F. Piccioli-Capelli, F. Hidalgo, F. C. Cardoso, E. Trevisi, and J. J. Loor. 2015. Abundance of ruminal bacteria, epithelial gene expression, and systemic biomarkers of metabolism and inflammation are altered during the peripartal period in dairy cows. J. Dairy Sci. 98:8940-8951. https://doi.org/10.3168/jds.2015-9722.

Mortha, A., A. Chudnovskiy, D. Hashimoto, M. Bogunovic, S. P. Spencer, Y. Belkaid, and M. Merad. 2014. Microbiota-dependent crosstalk between macrophages and ILC3 promotes intestinal homeostasis. Science 343:1249288. https://doi.org/10.1126/science .1249288

Nagaraja, T. G., E. E. Bartley, L. R. Fina, H. D. Anthony, and R. M. Bechtle. 1978. Evidence of endotoxins in the rumen bacteria of cattle fed hay or grain. J. Anim. Sci. 47:226-234. https://doi.org/ 10.2527/jas1978.471226x.

Najar, M., M. Krayem, N. Meuleman, D. Bron, and L. Lagneaux. 2017. Mesenchymal stromal cells and Toll-like receptor priming: A critical review. Immune Netw. 17:89-102. https://doi.org/10.4110/ in.2017.17.2.89.

Nierhaus, A., J. Linssen, M. S. Winkler, D. P. Frings, and S. Kluge. 2017. The effects of ex vivo administration of granulocyte-macrophage colony-stimulating factor and endotoxin on cytokine release of whole blood are determined by priming conditions. BioMed Res. Int. 2017:9834512. https://doi.org/10.1155/2017/9834512.

Nocek, J. E. 1997. Bovine acidosis: Implications on laminitis. J. Dairy Sci. 80:1005-1028. https://doi.org/10.3168/jds.S0022 -0302(97)76026-0.

Nomura, F., S. Akashi, Y. Sakao, S. Sato, T. Kawai, M. Matsumoto, K. Nakanishi, M. Kimoto, K. Miyake, K. Takeda, and S. Akira. 2000. Cutting edge: Endotoxin tolerance in mouse peritoneal macrophages correlates with down-regulation of surface Toll-like receptor 4 expression. J. Immunol. 164:3476-3479. https://doi.org/10 .4049/jimmunol.164.7.3476.

Ohtsuka, Y., J. Lee, D. S. Stamm, and I. R. Sanderson. 2001. MIP-2 secreted by epithelial cells increases neutrophil and lymphocyte recruitment in the mouse intestine. Gut 49:526-533. https://doi .org/10.1136/gut.49.4.526.

Owens, F. N., D. S. Secrist, W. J. Hill, and D. R. Gill. 1998. Acidosis in cattle: A review. J. Anim. Sci. 76:275-286. https://doi.org/10 $.2527 / 1998.761275 x$.

Pan, L. F., L. Yu, L. M. Wang, J. T. He, J. L. Sun, X. B. Wang, Z. H. Bai, H. Wang, T. L. Yan, and H. H. Pei. 2017. The Toll-like receptor 4 antagonist TAK-242 protects against chronic pancreatitis in rats. Mol. Med. Rep. 16:3863-3868. https://doi.org/10.3892/mmr .2017 .7105

Pasternak, J. A., D. J. MacPhee, and J. C. S. Harding. 2020. Fetal cytokine response to porcine reproductive and respiratory syndrome virus-2 infection. Cytokine 126:154883. https://doi.org/10.1016/j .cyto.2019.154883

Penner, G. B., M. Oba, G. Gabel, and J. R. Aschenbach. 2010. A single mild episode of subacute ruminal acidosis does not affect ruminal barrier function in the short term. J. Dairy Sci. 93:4838 4845. https://doi.org/10.3168/jds.2010-3406.

Penner, G. B., M. Taniguchi, L. L. Guan, K. A. Beauchemin, and M. Oba. 2009. Effect of dietary forage to concentrate ratio on volatile fatty acid absorption and the expression of genes related to volatile fatty acid absorption and metabolism in ruminal tissue. J. Dairy Sci. 92:2767-2781. https://doi.org/10.3168/jds.2008-1716.

Petzl, W., J. Gunther, T. Pfister, C. Sauter-Louis, L. Goetze, S. von Aulock, A. Hafner-Marx, H. J. Schuberth, H. M. Seyfert, and H. Zerbe. 2011. Lipopolysaccharide pretreatment of the udder protects against experimental Escherichia coli mastitis. Innate Immun. 18:467-477. https://doi.org/10.1177/1753425911422407.

Plaizier, J. C., M. Danesh Mesgaran, H. Derakhshani, H. Golder, E. Khafipour, J. L. Kleen, I. Lean, J. Loor, G. Penner, and Q. Zebeli. 2018. Review: Enhancing gastrointestinal health in dairy cows. Animal 12(Suppl. 2):s399-s418. https://doi.org/10.1017/ S1751731118001921.

Plaizier, J. C., E. Khafipour, S. Li, G. N. Gozho, and D. O. Krause. 2012. Subacute ruminal acidosis (SARA), endotoxins and health consequences. Anim. Feed Sci. Technol. 172:9-21. https://doi.org/ 10.1016/j.anifeedsci.2011.12.004.

Plaizier, J. C., D. O. Krause, G. N. Gozho, and B. W. McBride. 2008. Subacute ruminal acidosis in dairy cows: The physiological causes, incidence and consequences. Vet. J. 176:21-31. https://doi.org/10 $.1016 / j . t v j l .2007 .12 .016$.

Ricciotti, E., and G. A. FitzGerald. 2011. Prostaglandins and Inflammation. Arterioscler. Thromb. Vasc. Biol. 31:986-1000. https:// doi.org/10.1161/ATVBAHA.110.207449.

Schilling, J. D., S. M. Martin, C. S. Hung, R. G. Lorenz, and S. J. Hultgren. 2003. Toll-like receptor 4 on stromal and hematopoietic cells mediates innate resistance to uropathogenic Escherichia coli. Proc. Natl. Acad. Sci. USA 100:4203-4208. https://doi.org/ 10.1073/pnas.0736473100

Schindler, R., P. Ghezzi, and C. A. Dinarello. 1990. IL-1 induces IL1. IV. IFN-gamma suppresses IL-1 but not lipopolysaccharide-induced transcription of IL-1. J. Immunol. 144:2216-2222.

Seeley, J. J., and S. Ghosh. 2017. Molecular mechanisms of innate memory and tolerance to LPS. J. Leukoc. Biol. 101:107-119. https: //doi.org/10.1189/jlb.3MR0316-118RR.

Stadnyk, A. W. 2002. Intestinal epithelial cells as a source of inflammatory cytokines and chemokines. Can. J. Gastroenterol. 16:241246. https://doi.org/10.1155/2002/941087.

Steele, M. A., O. AlZahal, S. E. Hook, J. Croom, and B. W. McBride. 2009. Ruminal acidosis and the rapid onset of ruminal parakeratosis in a mature dairy cow: A case report. Acta Vet. Scand. 51:39. https://doi.org/10.1186/1751-0147-51-39.

Stumpff, F., M. I. Georgi, L. Mundhenk, I. Rabbani, M. Fromm, H. Martens, and D. Gunzel. 2011. Sheep rumen and omasum primary cultures and source epithelia: Barrier function aligns with expression of tight junction proteins. J. Exp. Biol. 214:2871-2882. https: //doi.org/10.1242/jeb.055582.

Sugimoto, M. A., L. P. Sousa, V. Pinho, M. Perretti, and M. M. Teixeira. 2016. Resolution of inflammation: What controls its onset? Front. Immunol. 7:160. https://doi.org/10.3389/fimmu.2016 .00160 .

Takeuchi, O., K. Hoshino, T. Kawai, H. Sanjo, H. Takada, T. Ogawa, K. Takeda, and S. Akira. 1999. Differential roles of TLR2 and TLR4 in recognition of gram-negative and gram-positive bacterial cell wall components. Immunity 11:443-451. https://doi.org/ 10.1016/S1074-7613(00)80119-3.

Trevisi, E., M. Amadori, F. Riva, G. Bertoni, and P. Bani. 2014. Evaluation of innate immune responses in bovine forestomachs. Res. Vet. Sci. 96:69-78. https://doi.org/10.1016/j.rvsc.2013.11.011.

Vallee, S., S. Laforest, F. Fouchier, M. P. Montero, C. Penel, and S. Champion. 2004. Cytokine-induced upregulation of NF-kappaB, IL-8, and ICAM-1 is dependent on colonic cell polarity: Implication for PKCdelta. Exp. Cell Res. 297:165-185. https://doi.org/10 .1016/j.yexcr.2004.03.007.

Watanabe, M., Y. Ueno, T. Yajima, Y. Iwao, M. Tsuchiya, H. Ishikawa, S. Aiso, T. Hibi, and H. Ishii. 1995. Interleukin 7 is produced by human intestinal epithelial cells and regulates the proliferation of intestinal mucosal lymphocytes. J. Clin. Invest. 95:2945-2953. https://doi.org/10.1172/JCI118002.

Wierenga, K. T., T. A. McAllister, D. J. Gibb, A. V. Chaves, E. K. Okine, K. A. Beauchemin, and M. Oba. 2010. Evaluation of triticale dried distillers grains with solubles as a substitute for barley 
grain and barley silage in feedlot finishing diets. J. Anim. Sci. 88:3018-3029. https://doi.org/10.2527/jas.2009-2703.

Yagi, S., A. Takaki, T. Hori, and K. Sugimachi. 2002. Enteric lipopolysaccharide raises plasma IL-6 levels in the hepatoportal vein during non-inflammatory stress in the rat. Fukuoka Igaku Zasshi 93:38-51.

Yang, R. B., M. R. Mark, A. L. Gurney, and P. J. Godowski. 1999. Signaling events induced by lipopolysaccharide-activated toll-like receptor 2. J. Immunol. 163:639-643.

Zhang, R., W. Zhu, and S. Mao. 2016. High-concentrate feeding upregulates the expression of inflammation-related genes in the ruminal epithelium of dairy cattle. J. Anim. Sci. Biotechnol. 7:42. https:// doi.org/10.1186/s40104-016-0100-1.
Zhang, W., J. Y. Du, Q. Yu, and J. O. Jin. 2015. Interleukin-7 produced by intestinal epithelial cells in response to Citrobacter rodentium infection plays a major role in innate immunity against this pathogen. Infect. Immun. 83:3213-3223. https://doi.org/10 .1128/IAI.00320-15.

\section{ORCIDS}

J. R. Aschenbach (1) https://orcid.org/0000-0001-5080-1007

P. J. Griebel (1) https://orcid.org/0000-0002-2450-9368

G. B. Penner (ㄴ) https://orcid.org/0000-0002-6396-2130 